\title{
Implementation of the full-scale emplacement (FE) experiment at the Mont Terri rock laboratory
}

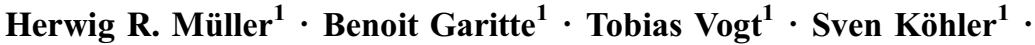 \\ Toshihiro Sakaki ${ }^{1}$ Hanspeter Weber ${ }^{1}$. Thomas Spillmann ${ }^{1} \cdot$ Marian Hertrich $^{1}$. \\ Jens K. Becker ${ }^{1} \cdot$ Niels Giroud $^{1} \cdot$ Veerle Cloet $^{1} \cdot$ Nikitas Diomidis $^{1}$. \\ Tim Vietor ${ }^{1}$
}

Received: 12 March 2016/Accepted: 9 December 2016/Published online: 16 February 2017

(C) The Author(s) 2017. This article is published with open access at Springerlink.com

\begin{abstract}
Opalinus Clay is currently being assessed as the host rock for a deep geological repository for high-level and low- and intermediate-level radioactive wastes in Switzerland. Within this framework, the 'Full-Scale Emplacement' (FE) experiment was initiated at the Mont Terri rock laboratory close to the small town of St-Ursanne in Switzerland. The FE experiment simulates, as realistically as possible, the construction, waste emplacement, backfilling and early post-closure evolution of a spent fuel/ vitrified high-level waste disposal tunnel according to the Swiss repository concept. The main aim of this multiple heater test is the investigation of repository-induced thermo-hydro-mechanical (THM) coupled effects on the host rock at this scale and the validation of existing coupled THM models. For this, several hundred sensors were installed in the rock, the tunnel lining, the bentonite buffer, the heaters and the plug. This paper is structured according to the implementation timeline of the FE experiment. It documents relevant details about the instrumentation, the tunnel construction, the production of the bentonite blocks and the highly compacted 'granulated bentonite mixture' $(\mathrm{GBM})$, the development and construction of the prototype
\end{abstract}

Editorial handling: P. Bossart and A. G. Milnes.

This is paper \#14 of the Mont Terri Special Issue of the Swiss Journal of Geosciences (see Bossart et al. 2017, Table 3 and Fig. 7).

Electronic supplementary material The online version of this article (doi:10.1007/s00015-016-0251-2) contains supplementary material, which is available to authorized users.

Herwig R. Müller

herwig.mueller@nagra.ch

1 Nagra, National Cooperative for the Disposal of Radioactive Waste, Hardstrasse 73, 5430 Wettingen, Switzerland 'backfilling machine' (BFM) and its testing for horizontal GBM emplacement. Finally, the plug construction and the start of all 3 heaters (with a thermal output of 1350 Watt each) in February 2015 are briefly described. In this paper, measurement results representative of the different experimental steps are also presented. Tunnel construction aspects are discussed on the basis of tunnel wall displacements, permeability testing and relative humidity measurements around the tunnel. GBM densities achieved with the BFM in the different off-site mock-up tests and, finally, in the FE tunnel are presented. Finally, in situ thermal conductivity and temperature measurements recorded during the first heating months are presented.

Keywords Opalinus Clay · Excavation - Backfilling · Bentonite - Sensor - Instrumentation · Heat · THM . Nuclear waste disposal

\section{Introduction}

\subsection{Experiment layout}

The Swiss repository concept for spent fuel/vitrified highlevel waste disposal tunnels (Nagra 2010) foresees the sequential emplacement of waste canisters in several hundred metre long horizontal tunnels in Opalinus Clay (Nagra 2014). The cylindrical waste canisters are to be emplaced in the middle of the tunnel section and separated from the tunnel wall by a bentonite buffer. The term bentonite buffer refers to all bentonite materials in a disposal tunnel. The bentonite buffer is part of the engineered barrier system and thus of the multi-barrier concept contributing to the retardation of radionuclides (Nagra 2002). At every 10th canister position, the concept foresees the installation of an 
'interjacent sealing section' (ISS) where the normal (cement-containing) tunnel support is replaced by e.g. steel sets in order to have direct contact between the rock and the 'bentonite backfill' and to intercept potential axial flow paths for radionuclides along the tunnel lining (Nagra 2010).

The layout of the 'Full-Scale Emplacement' (FE) experiment was designed to simulate these conditions in one single tunnel at the Mont Terri rock laboratory. First, a $50 \mathrm{~m}$ long experimental tunnel was constructed (Fig. 1). At the deep end of the FE tunnel an ISS was built using only steel sets for rock support, while the rest of the tunnel is supported by shotcrete. A bentonite block wall was erected manually in a section of the ISS. In the FE tunnel, 3 heaters with dimensions similar to those of waste canisters were emplaced on top of bentonite block pedestals. The first heater emplaced at the deep end of the FE tunnel was named H1, the middle one $\mathrm{H} 2$ and the most 'shallow' heater (close to the plug) H3. The remaining space was backfilled with a highly compacted 'granulated bentonite mixture' (GBM). For the purpose of backfilling the GBM as densely and homogeneously as possible into a horizontal tunnel, a prototype 'backfilling machine' (BFM) with 5 screw conveyors was developed. Finally, the experiment was sealed off (towards the FE cavern) with a concrete plug holding the bentonite buffer in place and reducing air and water fluxes.

\subsection{Experimental aims}

The FE experiment is the latest step in a series of investigations starting with small-scale laboratory tests (Villar et al. 2012), followed by mid-scale in situ heater experiments at the Mont Terri rock laboratory, such as the HE-D experiment (Gens et al. 2007, 2017) and the HE-E experiment (Gaus et al. 2014). With regard to its size and relevance, the FE experiment is comparable to large-scale heater experiments in other rock laboratories, such as the 'Full-scale Engineered Barrier Experiment' (FEBEX) at the Grimsel Test Site in Switzerland (Lanyon and Gaus
2013), the 'prototype repository' experiment at the ÄSPÖ rock laboratory in Sweden (Johannesson et al. 2004), the PRACLAY experiment in Boom Clay at the HADES rock laboratory in Belgium (Bernier et al. 2007) and the ALC experiment in Callovo-Oxfordian Clay at ANDRA's rock laboratory in France (Gugala 2015).

The main aim of the FE experiment is the investigation of high-level waste repository induced thermo-hydro-mechanical (THM) coupled effects on the host rock at this scale and the validation of existing coupled THM models (Müller et al. 2015). Further experimental aims are (i) the verification of the technical feasibility of constructing a disposal tunnel using standard industrial equipment, (ii) the optimisation of the bentonite buffer material production and (iii) the investigation of (horizontal) canister and bentonite buffer emplacement procedures for underground conditions (Weber et al. 2012; Bosgiraud et al. 2015).

It is outside the scope of this paper to present all the measurement results from the FE experiment; only a small selection is shown. For more details the reader is referred to Lisjak et al. (2015) on deformation measurements during the tunnel construction and Vogt et al. (2013) on the porewater pressure development during the tunnel construction.

\section{Geological overview}

The FE tunnel was constructed in the Mont Terri rock laboratory within the 'shaly facies' of the Opalinus Clay. For a detailed description of this strongly over-consolidated silty claystone ('shale'), the reader is referred to Bossart et al. (2017) and Hostettler et al. (2017).

\subsection{Natural discontinuities}

Details about the general tectonic setting of Mont Terri and the existing discontinuity network can be found in Bossart et al. (2017) and Nussbaum et al. (2017). The average dip of the bedding in the experimental area is $34^{\circ}$ towards the

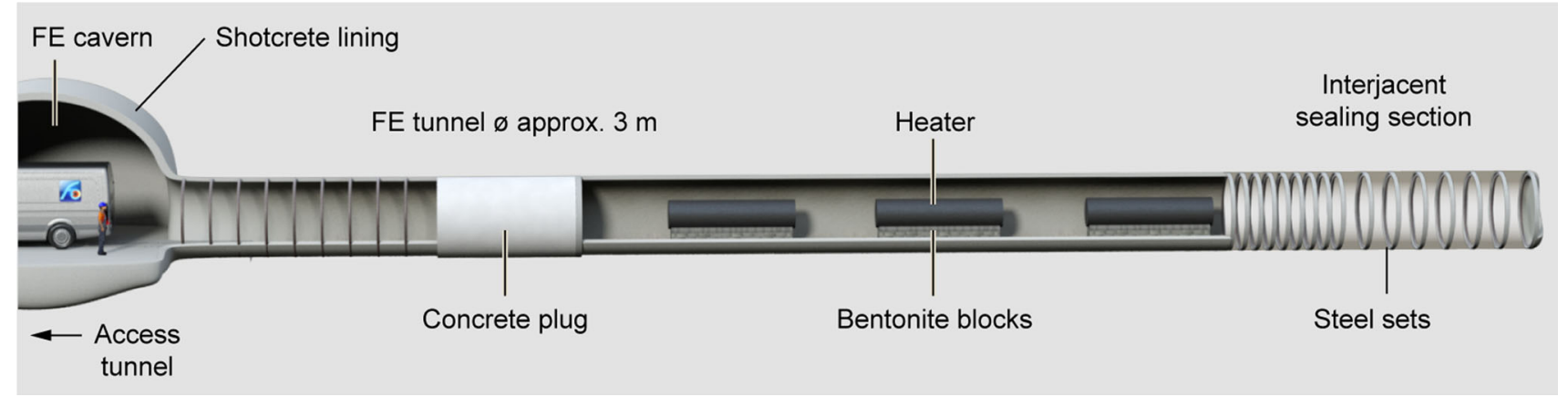

Fig. 1 Visualisation of the general layout of the FE experiment and the $50 \mathrm{~m}$ long FE tunnel at the Mont Terri rock laboratory; sensors, bentonite backfill and rock bolts are not shown 
south-east. With an excavation direction towards $244^{\circ}$, the axis of the FE tunnel is orientated approximately parallel to the strike of the bedding (Fig. 8).

While the FE cavern was not strongly faulted, a fault zone was encountered with the FE tunnel. This fault zone was oriented subparallel to the bedding and entered the tunnel at the lower right (north-western) side around 'tunnel metre' (TM) 14.5. The fault zone remained within the cross-section of the FE tunnel until the tunnel end at TM50. The fault was characterised by a heavily sheared core zone and strongly tectonised damage zone. The normal thickness of the fault zone varied between approximately $0.5-1.5 \mathrm{~m}$. The rock mass adjacent to the fault zone was characterised by countless sheared and polished bedding planes.

\subsection{Excavation damage zone}

The few 'excavation damage zone' (EDZ) features that could clearly be associated with the artificial fracturing process during tunnel excavation (Marschall et al. 2017) did not allow for a conclusive EDZ model, but suggested that the EDZ formation around the FE tunnel was strongly influenced by pre-existing discontinuities, reducing the formation of new EDZ features, for example, by reactivation (mainly shearing) of pre-existing slickensides.

This observation is consistent with the hydraulic conductivities determined in the close vicinity of the FE tunnel, which indicated a rather small EDZ. 8 hydraulic (double packer) tests in the far-field at a distance of 2.4$12.6 \mathrm{~m}$ from the FE tunnel wall resulted in a geometric mean of $6.4 \times 10^{-13} \mathrm{~m} / \mathrm{s}$. Moreover, 5 hydraulic (double packer) tests performed at a distance of 1.0-2.4 m from the tunnel wall showed slightly increased, but still very low, hydraulic conductivities with a geometric mean of $2.8 \times 10^{-12} \mathrm{~m} / \mathrm{s}$. In the very near-field up to $1 \mathrm{~m}$ from the tunnel wall, the observed pore-water pressure was less than $0.1 \mathrm{MPa}$. Only 1 hydraulic test was performed in this zone at a depth of $0.8-0.9 \mathrm{~m}$ from the tunnel wall, resulting in a hydraulic conductivity of $1.2 \times 10^{-10} \mathrm{~m} / \mathrm{s}$.

Similar observations were made by Shao et al. (2015) by means of gas permeability testing in radial boreholes in the shotcrete section and in the shotcrete-free ISS of the FE tunnel. In the shotcrete section, the extent of the gas-permeable EDZ with a permeability greater than $1 \times 10^{-18} \mathrm{~m}^{2}$ was found to be less than $1 \mathrm{~m}$, whereas in the ISS the gas-permeable EDZ was found to be larger than $2 \mathrm{~m}$. This is explained by the fact that the ISS was constructed with steel sets with sliding connections, resulting in a more 'ductile' tunnel support (compared to the shotcrete section) allowing long-term convergences and deformation and therefore the opening of discontinuities and EDZ features.

\section{Tunnel construction}

\subsection{FE cavern}

Before the start of the FE experiment, the FE cavern was constructed in the extension of the Mine-by (MB) experiment tunnel. This construction work included a local widening of 'Gallery 08' (GA08), especially around the portal of the MB tunnel, as well as renovation and reinforcement of the MB tunnel with steel sets and an additional shotcrete layer.

The FE cavern was excavated between November 2010 and May 2011. The size of the FE cavern allowed the use of a 15,000 kg CAT 312 excavator equipped with a rotary drum cutter ('road-header'). A remotely controlled BROKK 330 excavator was used for the confined spaces. Each of the 11 excavation steps was secured by implementing wire mesh reinforcement, installing and crosslinking steel sets and finally by applying shotcrete.

The reinforcement of the MB tunnel and the FE cavern was designed to ensure safe and long-term access to the FE tunnel. The shotcrete thickness in the FE cavern was more than $30 \mathrm{~cm}$ including 2 layers of K196 reinforcement steel mesh. The invert was up to $1.8 \mathrm{~m}$ deep and, after being backfilled, was finally covered with an even concrete floor. The resulting maximum (inner) dimensions of the tunnelshaped FE cavern are approximately $9 \mathrm{~m}$ (length) by $12 \mathrm{~m}$ (width) by $5 \mathrm{~m}$ (height).

\subsection{FE tunnel}

\subsubsection{Construction}

The $50 \mathrm{~m}$ long FE tunnel was constructed between April 2012 and July 2012 (Daneluzzi et al. 2014). The excavation was done with remotely controlled BROKK 260 and BROKK 90 excavators equipped mainly with a (pneumatically hammering) spade chisel and, for profiling, with a rotary drum cutter type SIMEX TF100 (Fig. 2). The excavation of the FE tunnel with an average external diameter of approximately $3 \mathrm{~m}$ and a cross-section of approximately $7 \mathrm{~m}^{2}$ was done full-face. Excavation steps were limited to $1.5 \mathrm{~m}$ per day in order to allow early rock support to be installed on the same day.

The different types of tunnel support, including the location of the monitoring and deformation measurement sections, can be seen in Fig. 3. From TM0 to TM38, the support in the tunnel consisted of mesh-reinforced shotcrete. The 'dry application' method was used for the shotcrete, adding water only at the spraying nozzle. The shotcrete was applied in two layers with a total thickness of at least $16 \mathrm{~cm}$. 1 layer of wire mesh K196 was installed in 


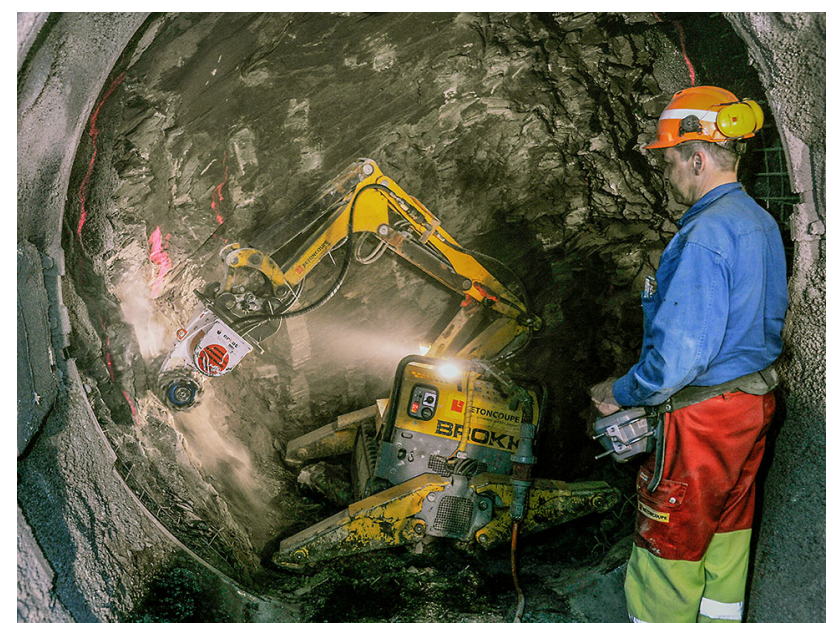

Fig. 2 Photo (by COMET) of the excavator (equipped with a small rotary drum cutter) used in the FE tunnel mainly for profiling

the first shotcrete layer. From TM9 to TM18 a third, approximately $10 \mathrm{~cm}$ thick layer of shotcrete with a second layer of wire mesh was installed. Due to the uneven rock surface (resulting e.g. from overbreaks), a shotcrete thickness of up to $50 \mathrm{~cm}$ was reached locally. Finally, the inner diameter of the FE tunnel was not perfectly round, varying diametrically between 2.5 and $2.7 \mathrm{~m}$.

At the deep end of the FE tunnel (from TM38 to TM50), an ISS was simulated using only steel sets (and reinforcement mesh) but no shotcrete for rock support (Fig. 4). In the FE tunnel, all steel sets were placed with a spacing of $1 \mathrm{~m}$, except in the ISS close to the shotcrete section where a $0.5 \mathrm{~m}$ spacing was chosen for safety and demonstration reasons. Each steel set was composed of several pieces with sliding connections that were tightened by bolts using a $300 \mathrm{Nm}$ torque spanner, allowing some movement after installation. The steel sets were bedded on grout-injected hoses in order to allow early load transfer (after hardening of the grout) and even load distribution from the rock onto the support element.

\subsubsection{Tunnel wall deformation monitoring}

The tunnel construction was surveyed using a total of 10 convergence measurement sections that were installed with an average spacing of approximately $6 \mathrm{~m}$ during the

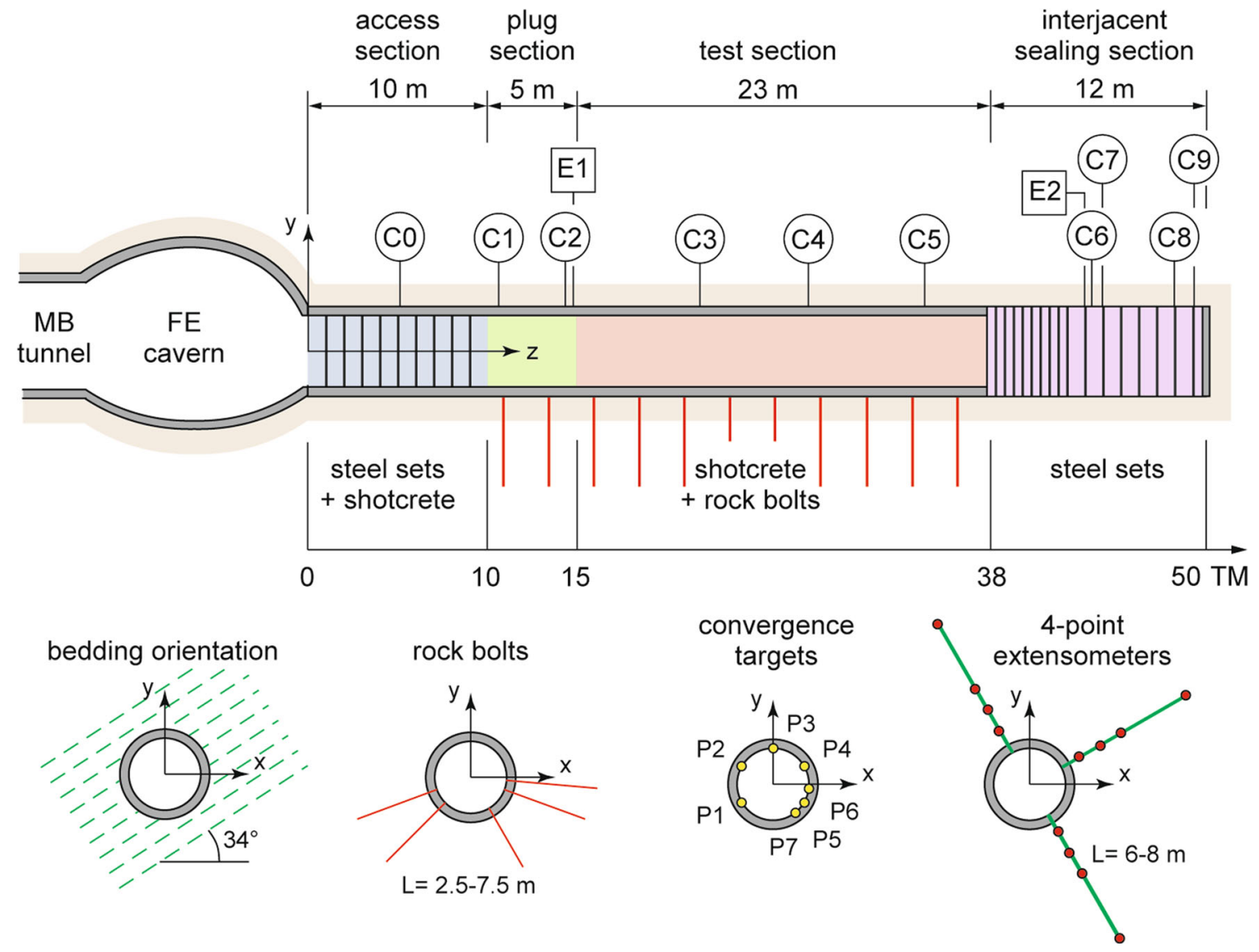

Fig. 3 Simplified longitudinal section (adapted from Lisjak et al. 2015) of the approximately $3 \mathrm{~m}$ diameter FE tunnel showing the different support measures, the convergence measurement sections
$(\mathrm{C} 0-\mathrm{C} 9)$ and the location of the radial extensometers (E1 and E2) installed during tunnel construction 

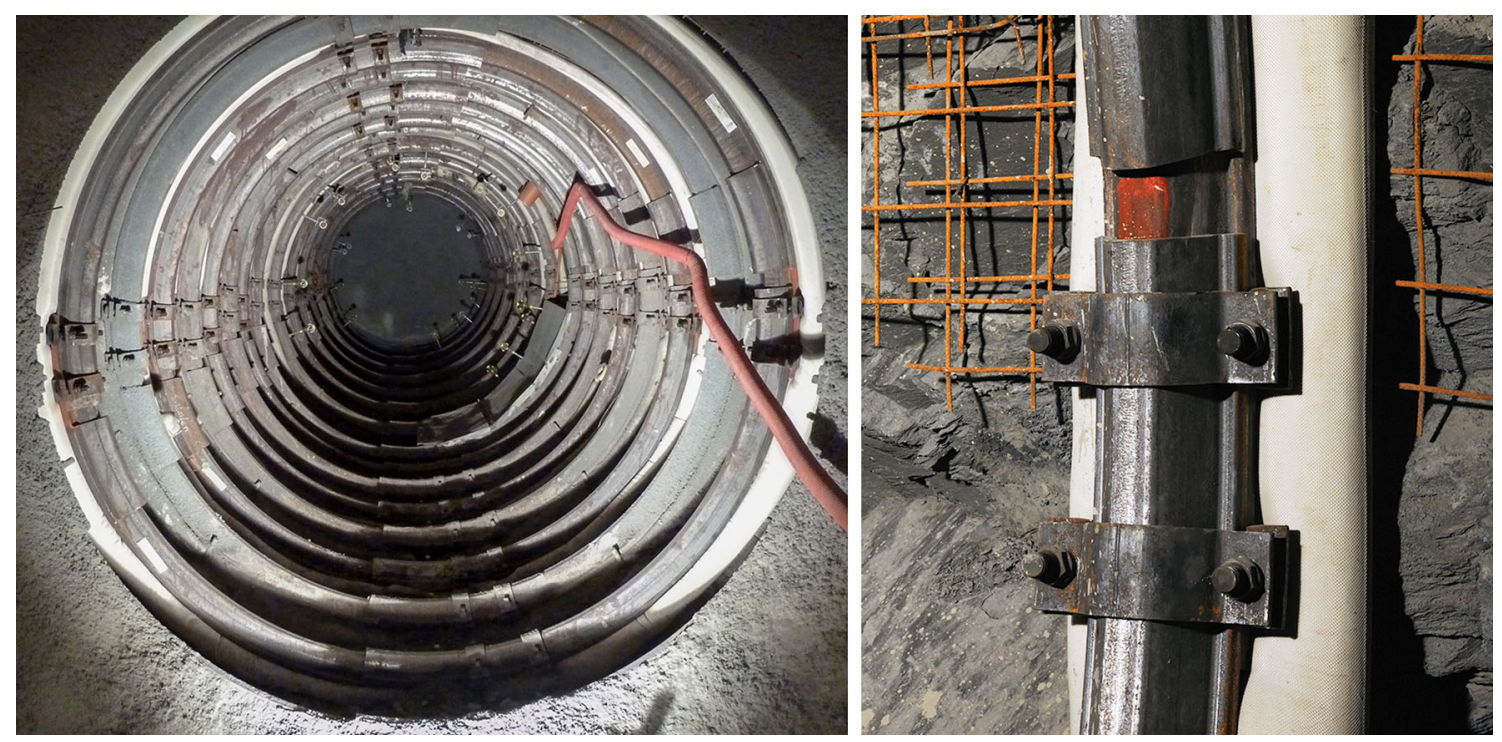

Fig. 4 The photo on the left shows the $12 \mathrm{~m}$ long shotcrete-free interjacent sealing section (ISS) at the end of the FE tunnel; the photo on the right shows a detail of a steel set bedded on a grout-injected hose for an even load distribution from the rock

excavation within the FE tunnel. In measurement sections C0 to $\mathrm{C} 4$ (Fig. 3), the radial configuration consisted of 5 observation targets; in measurement sections C5-C9 the radial configuration consisted of 7 observation targets. In total, 60 observation targets were installed. These targets (prismatic reflectors) were continuously monitored in 3D with a tachymeter during the tunnel construction until backfilling started approximately 30 months later.

All construction work was also monitored by INVAR wire convergence measurements, which showed similar results to the tachymetric tunnel wall deformation measurements. The long-term closing of the non-fixed ('sliding') steel set connections in the ISS was also monitored.

Whereas the steel set section showed normal deformation rates and a more or less symmetric tunnel wall convergence, the shotcrete section was initially characterised by an asymmetric tunnel wall convergence with several centimetres of deformation, particularly at the lower right (north-western) side of the tunnel (Fig. 5).

\subsubsection{Invert renovation}

Because of the observed deformation rates during the construction, $7.5 \mathrm{~m}$ long (steel) rock bolts were installed in the lower right (north-western) side wall of the tunnel in the shotcrete section from TM20 to TM38. Nevertheless, the shotcrete in the invert failed (Fig. 6) and had to be renewed. The renovation of the tunnel section from TM9 to TM38 was completed in September 2012. The old shotcrete in the invert was cut and removed segment by segment and new (mesh-reinforced) shotcrete was applied. During the renovation, extra $7.5 \mathrm{~m}$ long (steel) rock bolts were installed in the right (north-western) side wall of the tunnel. This was done in a pattern designed to prevent failure of the interface between the old and the new shotcrete lining. At the interface on the left side of the tunnel, $2.5 \mathrm{~m}$ long (fibre-reinforced plastic) rock bolts were installed in the same pattern.

The failure of the shotcrete invert was mainly caused by an irregular, not perfectly circular excavation profile and by the resulting shear and bending forces in the lining. An intensive coring and lab testing programme showed that the shotcrete in the invert did not have the required quality (although the strength targets were clearly met in the upper part of tunnel). Loose muck and rebound below the invert as well as layering within the shotcrete were detected. The shotcrete in the invert was also partially too unevenly and thinly applied, locally even of crumbling appearance and therefore too weak.

Apparently these circumstances contributed more to the failure of the invert than the properties of the faulted and tectonically weakened rock mass. This hypothesis is supported by the observation that, although constructed in the same geological setting, the steel set section generally showed a more homogeneous tunnel wall convergence and lower deformation rates than the shotcrete section (Fig. 5).

With the renovation work, the deformation rates in the shotcrete section were, if not stopped, reduced to a minimum. Until the concreting of the plug in March 2015 and afterwards, no further problems with the tunnel stability were encountered. 


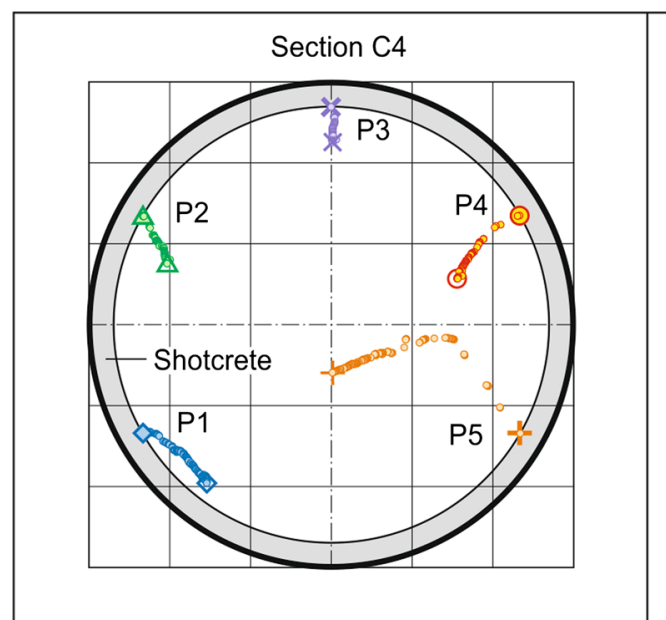

Fig. 590 day tunnel wall convergences at 2 example measurement sections C4 (left graph) and C7 (right graph). C4 was located in the shotcrete section of the FE tunnel at 'tunnel metre' (TM) 27.6 and C7 was located at TM44.2 in the shotcrete-free section supported only by

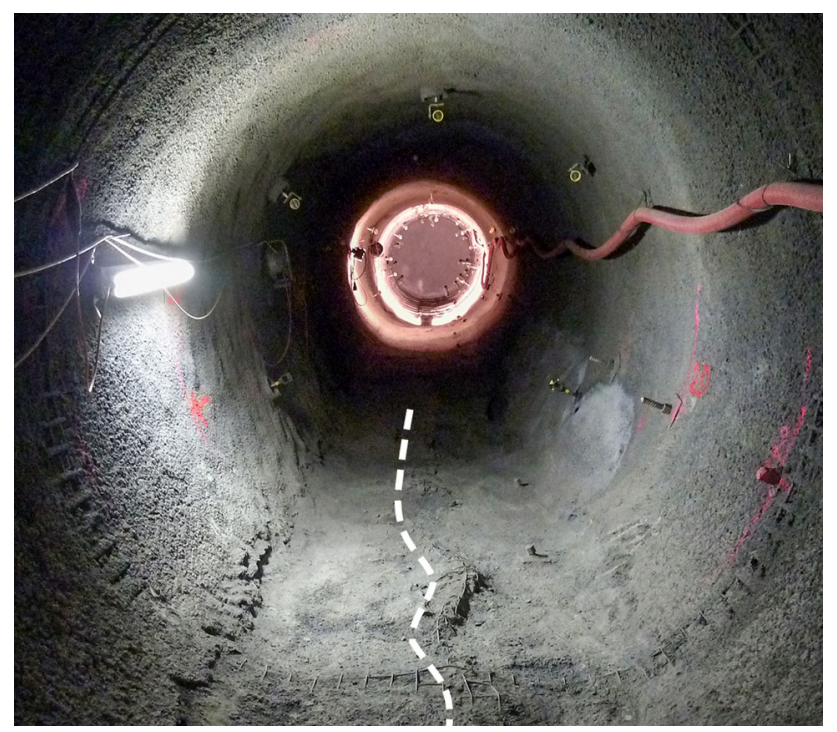

Fig. 6 Photo from the failed shotcrete invert (marked with a dashed white line) before the renovation in September 2012

\subsubsection{Shotcrete properties}

The basis of the shotcrete mixture design for the FE tunnel was the 'ESDRED mixture' developed within the framework of another EU project (Wetzig et al. 2011). In this low-pH shotcrete mixture, $40 \%$ of the Portland cement was substituted by silica fume. Silica fume reacts with calcium hydroxide ('pozzolanic reaction') to lower the $\mathrm{pH}$ value of the shotcrete. The reduction of the $\mathrm{pH}$ gradient between the (as a bulk) neutral clay minerals and the alkaline shotcrete limits chemical interactions, which is beneficial for the long-term safety of an engineered barrier system (Jenni et al. 2013).

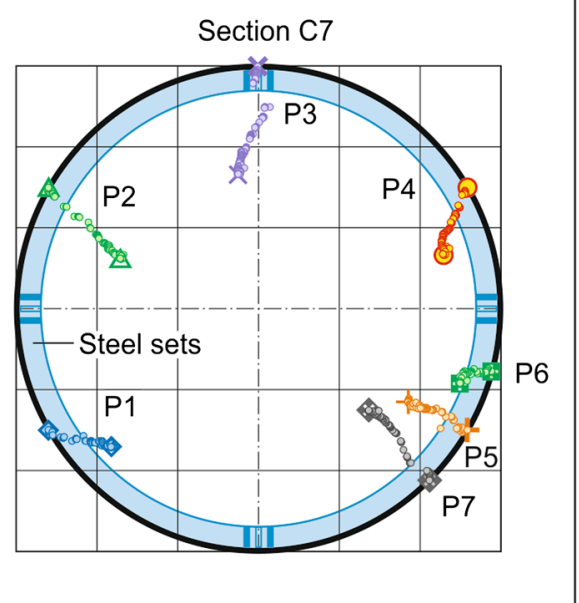

steel sets. The scale of the displacement vectors is amplified by a factor of 20 with respect to the excavated tunnel represented by a black circle. The right side of each graph represents the north-western side of the FE tunnel

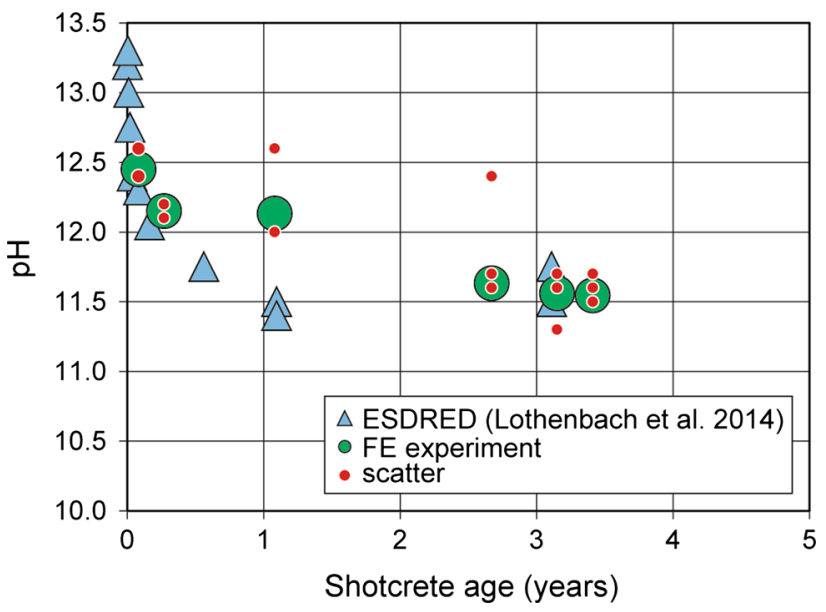

Fig. 7 The filled green circles show the $\mathrm{pH}$ values of FE samples measured under laboratory conditions at different shotcrete ages. The small red circles are all individual measurements. The values for the 'ESDRED mixture' as described in Lothenbach et al. (2014) are represented by blue triangles

$400 \mathrm{~g} / \mathrm{m}^{3}$ of superplasticizer were added to the FE mixture but, differently than in the 'ESDRED mixture', no accelerator was used in order to reduce the content of organic matter.

The $\mathrm{pH}$ value of the shotcrete samples was measured under laboratory conditions by the ex situ leaching method (Alonso et al. 2012) after 90, 111 days, 1 and 3.4 years. The $\mathrm{pH}$ value of the shotcrete samples from the FE tunnel showed an ongoing decrease with time; from an initial value of approximately 12.4 , the $\mathrm{pH}$ decreased within 3.4 years to a value of approximately 11.5 (Fig. 7). According to modelling results by Lothenbach et al. (2014), the 'ESDRED mixture' should reach an 
Table 1 Averages of measurement results on shotcrete samples from the FE tunnel

\begin{tabular}{ll}
\hline Parameter & Average value \\
\hline Total porosity & $23.1 \mathrm{vol} \%$ \\
Free water content & $4.7 \mathrm{wt} \%$ \\
Water permeability & $1.15 \times 10^{-17} \mathrm{~m}^{2}$ \\
Thermal conductivity & $1.7 \mathrm{~W} / \mathrm{mK}$ \\
Uniaxial compressive strength & $42.4 \mathrm{MPa}$ after 28 days $/ 50.4 \mathrm{MPa}$ after 90 days \\
\hline
\end{tabular}

equilibrium $\mathrm{pH}$ value of 11.5 after 1 year and will slowly decrease to a $\mathrm{pH}$ of 11 after a long period of time; the same can be assumed for the FE mixture. Measurement results of selected physical properties of the FE shotcrete are presented in Table 1.

\section{Instrumentation}

The entire experiment implementation as well as the postclosure THM evolution of this full-scale heater experiment is monitored using several hundred sensors (Table 2). The main monitored parameters are temperature, pressure, deformation and humidity/water content. The sensors are distributed in boreholes, in the tunnel lining, in the bentonite buffer and on the heaters (Fig. 8). Their installation was performed sequentially in the following main phases: (i) instrumentation of the rock mass in the tunnel far-field before the tunnel excavation (November 2011 until April 2012), (ii) instrumentation of the rock mass in the tunnel near-field during the tunnel construction (May until June 2012) and afterwards (December 2012 until February 2014), (iii) instrumentation of the bentonite buffer, where firstly the sensors on the tunnel wall were installed (May until June 2014); finally the sensors on, and in close proximity to, the heaters were emplaced together with the 3 heaters in October 2014, November 2014 and January 2015.

The monitoring environment of the FE experiment is challenging, because a long observation period of at least 10-15 years is envisaged and because high temperatures of up to $130-150{ }^{\circ} \mathrm{C}$ at the heater surface and of up to $60-80^{\circ}$ $\mathrm{C}$ at the tunnel wall are expected. In addition, the porewater with a salinity of more than $35 \mathrm{mS} / \mathrm{cm}$ might enhance corrosion of metallic sensor components in the rock and in the humid (partially water-saturated) bentonite buffer close to the tunnel wall.

Due to these conditions, besides standard state-of-the-art sensors, fibre-optic sensors as well as modified and prototype measurement systems were also installed. The prototype systems were designed to be more corrosionresistant. They were also constructed to be less heat-conductive, reducing the impact of the instrumentation on the experiment evolution.

\subsection{Tunnel climate}

Climate sensors measuring air humidity, air temperature, air pressure and air velocity were installed in the FE cavern and at several locations in the FE tunnel. These sensors monitored the tunnel climate before and during the tunnel excavation, but wherever possible also during the actively ventilated phase until the completion of tunnel backfilling.

\subsection{Instrumentation of the rock}

In general, the borehole instrumentation was set up parallel, perpendicular and oblique to the bedding, taking the anisotropy of the Opalinus Clay into consideration. The rock mass in the far-field of the FE tunnel was instrumented with up to $45 \mathrm{~m}$ long boreholes drilled from the FE cavern (Fig. 8). This instrumentation was completed in April 2012 before the FE tunnel was excavated and therefore allowed a 'mine-by' observation of the later excavation. The rock mass in the near-field of the FE tunnel was instrumented with (several metre long) radial boreholes drilled from the FE tunnel partially during, but mainly after, the tunnel construction.

\subsubsection{Pore-water pressure}

In 6 boreholes drilled from the FE cavern, multi-packer systems with a total of 36 pore-water pressure monitoring intervals were implemented before the start of the tunnel excavation. Additionally, two single packer systems with 1 pore-water pressure monitoring interval each were installed before the start of the tunnel excavation.

For pore-water pressure monitoring in the rock close to the FE tunnel, after the tunnel construction was completed, 8 radial boreholes were instrumented with multi-packer systems and 2 intervals each and, additionally, 11 boreholes were instrumented with single packer systems and 1 interval each.

\subsubsection{Deformation}

Before the tunnel excavation, horizontal inclinometer chains (with 40 segments each) were installed in two boreholes located above the FE tunnel, drilled sub-parallel 
Table 2 Approximate number of sensors installed as part of the FE experiment during the different instrumentation phases

\begin{tabular}{lccrr}
\hline Instrumentation & Phase 1 (tunnel far-field) & Phase 2 (tunnel near-field) & Phase 3 (bentonite buffer) & Total \\
\hline Temperature & 480 & 140 & 580 & 1200 \\
RH, TDR, etc. & 0 & 54 & 23 & 173 \\
Deformation & 80 & 44 & 30 & 147 \\
Total pressure & 36 & 27 & 0 & 72 \\
Pore-water pressure & 38 & 0 & 20 & 65 \\
Gas composition & 0 & 271 & 772 & 20 \\
Total & 634 & 677 & 167 \\
\hline
\end{tabular}

Not included in this table are the thermal conductivity sensors, the geophysical sensors, the gas sampling lines, the material samples, the plug instrumentation and some fibre-optic systems

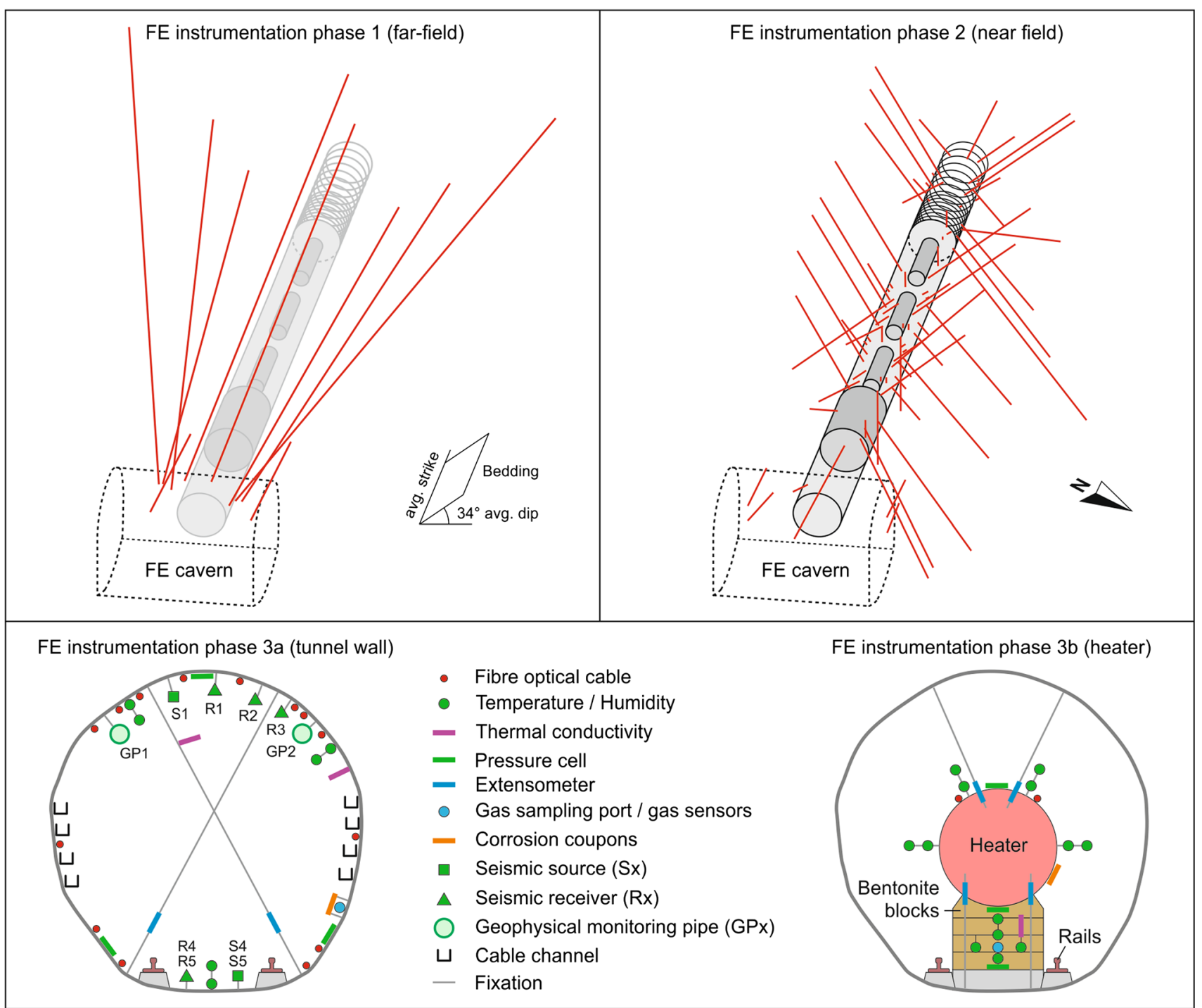

Fig. 8 Overview showing the main instrumentation phases of the FE experiment. The graphs at the top also indicate the borehole arrangements around the $50 \mathrm{~m}$ long FE tunnel. The graphs at the bottom represent strongly simplified summaries of the many different instrumentation cross-sections within the 2.5-2.7 m diameter FE tunnel 
to the tunnel axis. During the tunnel construction, five standard rod extensometers each with four displacement sensors and a length of 6-8 $\mathrm{m}$ were installed in radial boreholes drilled from within the FE tunnel (sections E1 and E2 in Fig. 3). Thereafter, an additional 6 radial boreholes were instrumented with specially designed longlasting rod extensometers and seven radial boreholes were equipped with fibre-optic extensometers.

\subsubsection{Temperature}

In general, most boreholes were equipped with temperature sensors at different depths. In total, 260 conventional temperature sensors (thermocouples and PT1000) were installed as well as $360 \mathrm{~m}$ of fibre-optic cable for distributed temperature sensing.

\subsubsection{Humidity/water content}

The development of the 'water content' (WC) of the rock mass around the FE tunnel is being monitored with a commercial dielectric profile probe originally developed for agricultural applications. This dielectric tool has 6 measurement sections within its $1 \mathrm{~m}$ length. A total of 5 of these probes were permanently installed in $28 \mathrm{~mm}$ diameter boreholes drilled in the 'cooler' sections of the FE tunnel.

Figure 9 shows the WC profiles of the Opalinus Clay around the FE tunnel measured using the dielectric profile probes. The data indicate a difference between sections where the rock is covered with shotcrete and the unlined sections. In the profiles without shotcrete, desaturation reaches about $50 \mathrm{~cm}$ into the rock, whereas the rock behind the shotcrete seems to be fully saturated, with only minor signs of desaturation in the shotcrete itself.

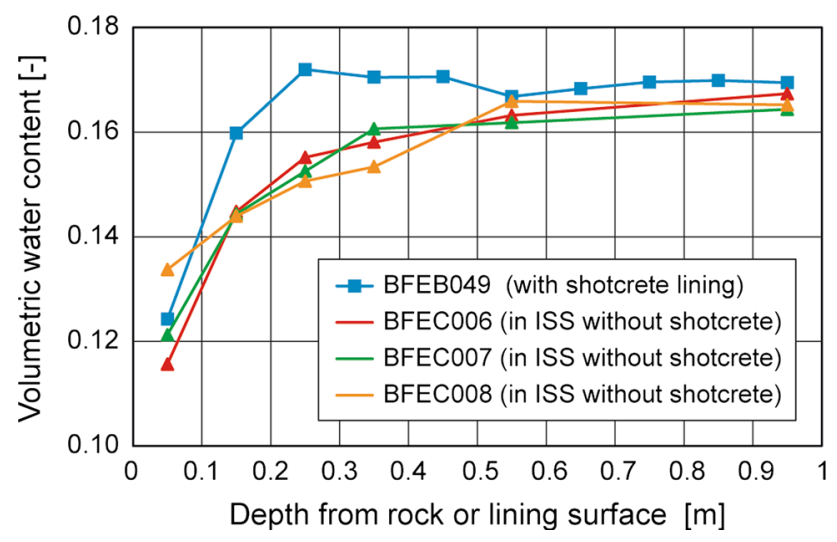

Fig. 9 Water content profiles measured with the dielectric profile probe in selected $1 \mathrm{~m}$ long boreholes, drilled radially from the $\mathrm{FE}$ tunnel, showing a clear difference between unlined rock and rock covered with shotcrete
The second type of sensor used for the rock moisture monitoring was designed specifically for use in the 'hotter' sections in the FE experiment close to the heaters. To withstand long-term use under high temperatures, 'time domain reflectometry' (TDR) was selected. The design of the sensor allowed all vulnerable electronic parts to be placed outside the heated tunnel Sect. 6 probes with a total of 24 TDR sensors were installed in a Y-shaped configuration around the middle heater $\mathrm{H} 2$ and around the 'shallow' heater H3 (Sakaki et al. 2014).

Finally, 17 radial boreholes were equipped with standard and monolithic capacitive 'relative humidity' (RH) sensors. The boreholes were $0.2-0.5 \mathrm{~m}$ deep and had a diameter of $28 \mathrm{~mm}$.

\subsection{Instrumentation of the bentonite buffer}

Many sensors on the tunnel wall and on the heaters had to be installed on erectable sensor holders due to the space conflict with the prototype machine developed for backfilling the FE tunnel.

\subsubsection{Total pressure and deformation}

24 Total pressure cells were installed on the tunnel wall and 2 total pressure cells on the surface of each heater in order to monitor any potential swelling pressure of the bentonite buffer. Furthermore, a total of 23 displacement sensors were installed to track any potential heater movement or tunnel wall deformation after backfilling and during heating. Approximately $120 \mathrm{~m}$ of fibre-optic cables were also installed at different positions along the tunnel for distributed strain sensing.

\subsubsection{Temperature}

Each heater was equipped with 6 internal thermocouples and 18 external thermocouples (fixed to the heater surface). In addition, each heater surface was equipped with 24 fibreoptic point sensors. The spatio-temporal temperature distribution and evolution of the tunnel wall and of the bentonite buffer is monitored by a total of 238 temperature sensors, of which 105 are conventional sensors (thermocouples and PT1000) and the rest are integrated into RH and total pressure sensors. In addition, approximately $300 \mathrm{~m}$ of fibre-optic cables were installed at different positions on the tunnel wall for distributed temperature sensing.

\subsubsection{Humidity/water content}

A total of $99 \mathrm{RH}$ sensors were installed within the bentonite buffer. Additionally, a total of 6 customised TDR 
probes were installed around and between heater $\mathrm{H} 2$ and heater $\mathrm{H} 3$.

\subsubsection{Thermal conductivity}

Around and between the heaters $\mathrm{H} 2$ and $\mathrm{H} 3$, a total of 15 thermal conductivity sensors were installed within the GBM and the bentonite blocks. Each of these heat pulse sensors consisted of a single $10 \mathrm{~cm}$ long needle. First measurement results show that the initial thermal conductivity of the GBM at the achieved bulk 'dry density' (DD) in the backfilled FE tunnel was $0.29 \pm 0.05 \mathrm{~W} / \mathrm{mK}$ and that a slight increase can be observed over the course of the first 12 months after the start of heating (Fig. 10).

\subsubsection{Geophysical monitoring}

Geophysical methods were selected with the aim of monitoring changes in the bentonite buffer in a quantitative manner with minimal adverse effects on the backfilling procedure or the THM evolution. One monitoring component consists of 2 gas-tight pipes installed approximately $1.7 \mathrm{~m}$ apart in the roof of the FE tunnel at a distance of a few centimetres from the shotcrete liner. These pipes facilitate long-term access through the concrete plug and into the bentonite buffer in front of and above the 'shallow' heater $\mathrm{H} 3$ for a variety of geophysical borehole tools. Measurement campaigns with the focus on bentonite properties in the near-field around the pipes include repeated density and porosity logging as well as single-hole georadar surveys. Tomographic georadar and acoustic surveys are performed to better capture and image the changes in the area between the two pipes. An acoustic 'borehole' sensor system (with 1 source and 8 receivers) is typically kept at a fixed position in the pipes for quasi-

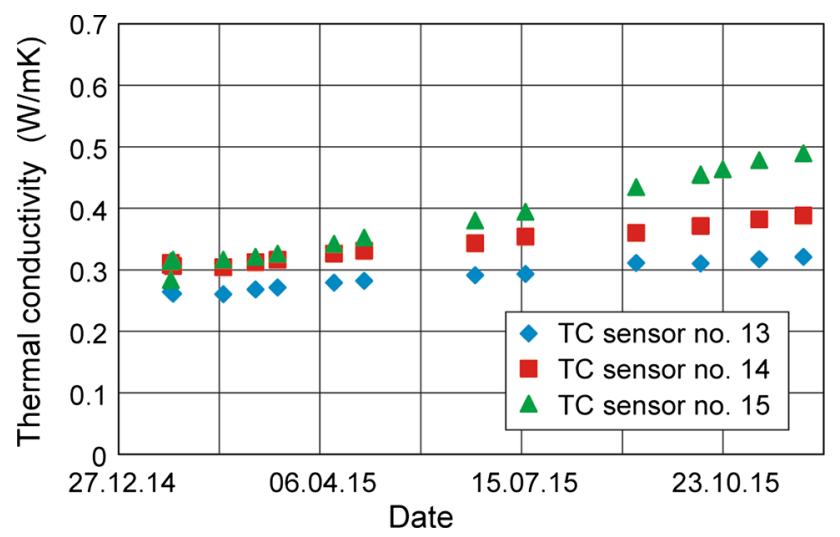

Fig. 10 Time series plot showing how the thermal conductivity of the backfilled GBM increased slightly over time. This example is from three measurement locations close to the tunnel wall around heater $\mathrm{H} 3$ continuous monitoring of transients between different measurement campaigns.

The second monitoring component includes two acoustic sensor arrays that were permanently installed before backfilling, one close to the floor and one in the roof of the tunnel (Fig. 8; 'seismic source' and 'seismic receiver' in lower left graph). These permanent installations allow subtle changes in acoustic waveforms to be captured either within the individual arrays or across the arrays when sensor coupling is sufficient. In combination with the acoustic 'borehole' sensor system temporarily installed in the pipes, additional ray paths and imaging capabilities can be tested.

\subsubsection{Gas composition}

14 Prototype in situ hydrogen and 6 in situ oxygen concentration sensors were installed at different locations along the FE tunnel. The 2 most 'shallow' oxygen sensors were located on the GBM side of the plug retaining wall at TM15; the 'deepest' one was placed in the ISS at TM43. Additionally, 10 gas sampling lines were installed to allow continuous gas monitoring by mass spectrometry as well as periodic gas sampling. The sampling lines chosen were PEEK with an inside diameter of $1.5 \mathrm{~mm}$. The backfilled sampling points consist of a PVDF housing with either a stainless steel filter or a silver-coated nylon mesh. The silver coating should hinder the development of biofilms, which could lead to clogging of the filters.

At all locations (with the exception of directly behind the plug retaining wall), the oxygen concentrations drop to approximately $0 \%$ within 2-3 months after backfilling (Fig. 11).

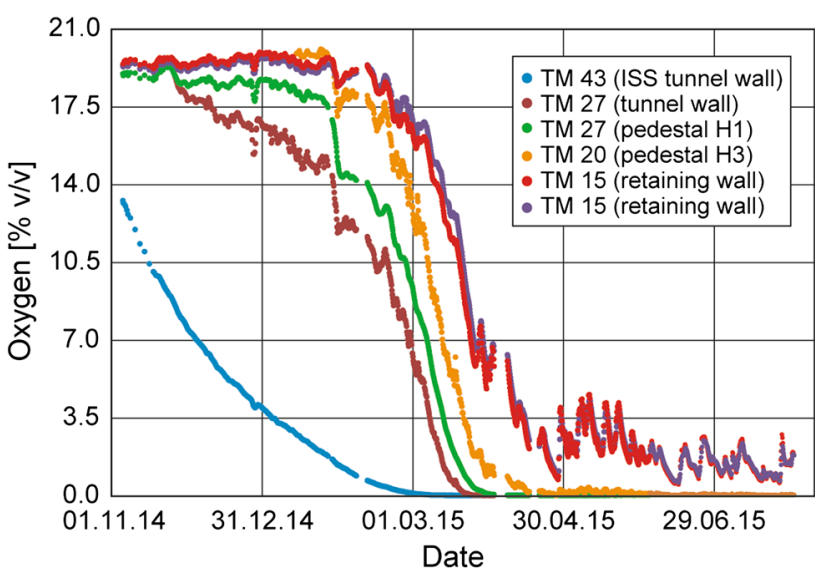

Fig. 11 Oxygen concentrations at different measurement locations along the FE tunnel from November 2014 (shortly after backfilling started) until July 2015 
Table 3 Material specifications required for the raw bentonite used in the FE experiment

\begin{tabular}{ll}
\hline Criterion & Requirements \\
\hline Material & Natural (non-activated) sodium bentonite \\
Smectite content by dried weight, measured by X-ray diffraction using a dried sample & $>75 \%$ \\
Additives (magnetite, baryte, binders, etc.) & No additives allowed \\
CEC (Cation Exchange Capacity), measured by Cu(II)-triethylenetetramine method & $>70$ meq/100 g \\
Pyrite content by dried weight, measured by X-ray diffraction using a dried sample & $<1 \%$ \\
Sulphur content by dried weight, measured by emission or mass spectroscopy & $<0.5 \%$ (corresponds to ca. $1 \%$ of pyrite) \\
Organic carbon by dried weight, measured by emission or mass spectroscopy & $<1 \%$ \\
\hline
\end{tabular}

\subsubsection{Corrosion monitoring}

In order to investigate in situ corrosion phenomena in the case of potential future dismantling of the FE experiment, sample holders with different metals were installed on heaters $\mathrm{H} 2$ and $\mathrm{H} 3$ as well as at two different locations on the tunnel wall in close proximity to the gas sensors and sampling ports. The metals used in the sample holders were carbon steel, wrought copper, electrodeposited copper and cold-sprayed copper. 5 corrosion coupons from each metal were installed at each position. The corrosion coupons were polished and their surface roughness characterised prior to emplacement.

\section{Bentonite buffer production}

Bentonite is considered as a potential sealing and backfill material in most concepts for geological disposal of radioactive waste. Bentonite is essentially a natural clay mixture consisting mostly of montmorillonite of volcanic, hydrothermally altered origin. There are two main types of bentonite on the market: calcium-rich and sodium-rich depending on the dominant interlayer cation $\left(\mathrm{Ca}^{2+} / \mathrm{Na}^{+}\right)$. Sodium-rich bentonite was chosen for the FE experiment, based on the requirements specified by Karnland (2010) and Leupin et al. (2014). Table 3 summarises the raw material specifications that had to be fulfilled during the bentonite buffer production for the FE experiment and that were checked by independent laboratories.

\subsection{Bentonite blocks}

\subsubsection{Test production}

Compacted bentonite blocks can disintegrate in contact with ambient air. With a test production, a simple novel concept was introduced to estimate the resistance of compacted bentonite to changing climatic conditions. In
November 2012, 90 bentonite blocks compacted at three different water contents $(12,16$ and 19\%) and three different compaction pressures $(70,100$ and $130 \mathrm{MPa})$ were produced using sodium bentonite (Garitte et al. 2015). Two blocks from each 'water content' (WC)/compaction pressure group were emplaced in sealed plastic bags with 'relative humidity' (RH) sensors to determine their equilibrium RH. The equilibrium RH was found to lie between 50 and $70 \%$ and increased with the WC.

The blocks then were submitted to "uniaxial compressive strength' (UCS) testing in several series. In the first series, the blocks were tested directly after production. In the next series, the blocks were first placed in climate chambers with different relative air humidities of 35, 50, 70 and $90 \%$ until the blocks reached equilibrium. The UCS test results clearly show that imposing a $\mathrm{RH}$ on a bentonite block higher than its equilibrium RH drastically reduces its strength. On the other hand, imposing a RH on a block lower than its equilibrium RH leaves the block strength unaffected. Blocks with a high equilibrium RH are thus likely to be more resistant to $\mathrm{RH}$ variations.

\subsubsection{Long-term load test}

A long-term load test was set up to verify the previous laboratory test results and to investigate the involved mechanisms phenomenologically. Four groups of blocks with different initial production parameters (WC and compaction pressure) were emplaced in September 2013 at the Grimsel Test Site in Switzerland. The RH in the tunnel air at that time varied around $70 \%$. All block sets were loaded with a pressure similar to the one exerted by a heater on a bentonite block pedestal in the FE experiment.

Blocks compacted at a low WC disintegrated in a short period of time. Only hours after the start of the test cracks appeared, which propagated quickly. The cracks were generated by swelling, caused by water absorption of the relatively dry bentonite from relatively wet air. The support capability of the low WC blocks was lost within only 
1 month. Blocks produced with a high $\mathrm{WC}$, and thus characterised by a higher equilibrium $\mathrm{RH}$, on the other hand, took up nearly no water and proved to be very stable over a long period of time ( $>1.5$ years).

The equilibrium RH allows whether or not a compacted bentonite block will disintegrate in ambient conditions to be determined according to the following simple rule: a bentonite block is stable as long as the $\mathrm{RH}$ of the ambient air does not exceed its equilibrium RH by more than 5$10 \%$. This concept proved to be successful as no bentonite blocks were affected during the emplacement operations of the FE experiment.

\subsubsection{Full-scale load tests}

In April 2014 a short-term, full-scale load test was set up at the Grimsel Test Site. This test was performed to check the maximum load a bentonite block pedestal can take and to verify the upscaling results obtained by 'hybrid finite-discrete element method' (FEMDEM) modelling using mechanical parameters derived from laboratory tests.

The test set-up for this full-scale load test consisted of a bentonite block pedestal with the same dimensions (in a transversal section) as in the FE experiment, which was loaded vertically (Fig. 12). The test was performed in ambient air RH lower than the block equilibrium RH. It was found that, under these conditions, a FE-sized

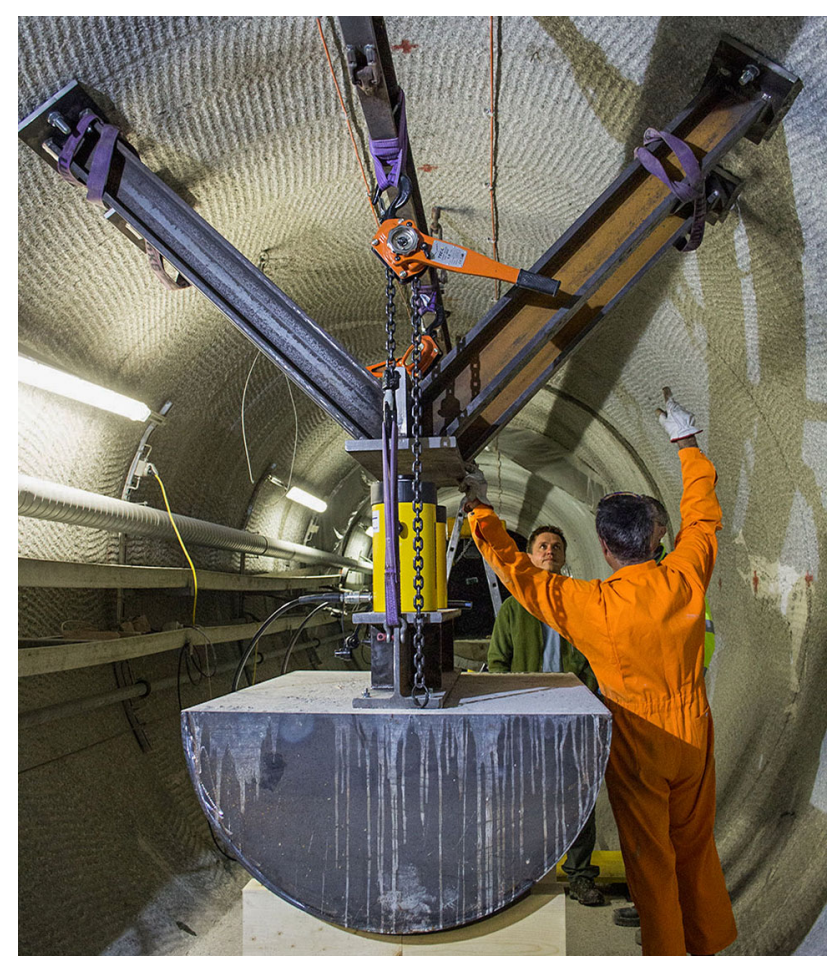

Fig. 12 Test set-up of the full-scale load test of a bentonite block pedestal at the Grimsel Test Site bentonite block pedestal can support loads of more than $1,000,000 \mathrm{~kg}$.

\subsubsection{Main block production}

After concluding all test productions and pre-tests, the block production parameters for the FE experiment were set to obtain stable blocks that are able to support the $5000 \mathrm{~kg}$ heaters under the expected climatic conditions at the Mont Terri rock laboratory. The chosen production parameters were (i) a raw material WC (= mass of water lost during oven drying at $105{ }^{\circ} \mathrm{C}$ divided by the dry mass of the material) of $18 \%$ and (ii) a compaction pressure of $130 \mathrm{MPa}$. With these production parameters, around 2500 rectangular blocks (each with a weight of $24.4 \mathrm{~kg}$ and dimensions of $40 \mathrm{~cm}$ by $20 \mathrm{~cm}$ by $14.5 \mathrm{~cm}$ ) and 500 curved 'top layer' blocks (each with a weight of $11.65 \mathrm{~kg}$ and dimensions of $40 \mathrm{~cm}$ by $10 \mathrm{~cm}$ by $10.7-20.5 \mathrm{~cm}$ ) were produced in March 2014 from the raw material 'MPC Bentosund WH2' (Garitte et al. 2015).

The bentonite blocks were produced at a rate of 1 block per minute using a natural sodium bentonite. The selected compaction pressure and WC resulted in an average 'dry density' (DD) of $1.78 \mathrm{~g} / \mathrm{cm}^{3}$. Besides compaction pressure and WC, the following parameters were submitted to an intensive quality control, acting as rejection criteria during the block production: (i) block dimensions, (ii) density, (iii) no visible cracks/damage and (iv) a minimum UCS of $6 \mathrm{MPa}$.

\subsubsection{Block storage}

After production, the bentonite blocks were stacked on pallets and then wrapped tightly with plastic foil to prevent water absorption from the environment, which could have caused damage. $5 \%$ of the pallets were equipped with a wireless RH sensor to detect potential leakage of the packaging. All RH sensors showed that the tightness of the pallet packaging was assured throughout the storage period and that the bentonite blocks were unaffected by the $\mathrm{RH}$ evolution outside the packaging.

\subsection{Granulated bentonite mixture}

The raw bentonite material needed for the production of the highly compacted and 'granulated bentonite mixture' (GBM) used for backfilling the FE tunnel was obtained through open tender (Garitte et al. 2015). Approximately $350,000 \mathrm{~kg}$ of raw bentonite ('CEBO National Standard') were transformed into a GBM. The aim of the GBM production process was to increase the bulk DD of the raw bentonite material (approximately $0.9 \mathrm{~g} / \mathrm{cm}^{3}$ ) to an emplaced DD of at least $1.45 \mathrm{~g} / \mathrm{cm}^{3}$. 
Blümling and Adams (2008) presented a summary of the work carried out on the use of bentonite pellets as backfilling material within the framework of a borehole sealing project. The authors showed in a very systematic way that the emplaced DD is dependent on (i) the DD of individual pellets, (ii) the grain size distribution of the mixture, (iii) the pellet particle shape and (iv) the emplacement method.

The production of a GBM includes several processing steps (Hoffmann et al. 2007). For the FE experiment, the raw material was provided at a WC of about $10-15 \%$. It was then dried by heating to obtain a lower WC in the range of $4-6 \%$, close to the Proctor's optimum, which is associated with a higher pellet DD. The maximum temperature to which the raw bentonite was exposed during the drying process was $80{ }^{\circ} \mathrm{C}$. Considering the upper temperature limit, the drying capacity depended exclusively on the grain size distribution of the raw material and the residence time in the heating chamber. Approximately $1500 \mathrm{~kg}$ of raw bentonite were dried per hour in the production for the FE experiment.

The aim during the pelletising process is to increase the pellet DD. For the FE experiment, the pellets were produced by compaction between flat rollers (resulting in pellets of irregular shape). Although alternative methods exist (Pietsch 2004), this method was found to be better from an economic point of view, with a reasonable production rate (1000-2000 $\mathrm{kg}$ per h). The negative side of this production method was that the desired maximum grain size could not be reached. The bentonite pellets produced were then mixed in a Kniele mixer, providing enough energy to break some of the pellets, resulting in a mixture with a broad grain size distribution (Fig. 13), the aim being to fill larger pores between large particles with smaller particles at all scales. A specific mixing cycle was

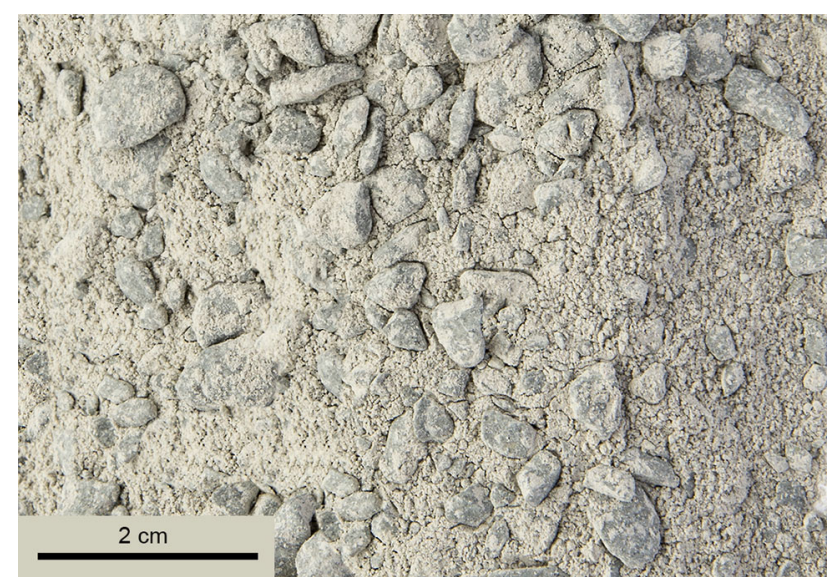

Fig. 13 Photo of the highly compacted 'granulated bentonite mixture' (GBM) produced for the FE experiment. For the individual pellets, an average dry density of $2.18 \mathrm{~g} / \mathrm{cm}^{3}$ was achieved by compaction between flat rollers designed to obtain a grain size distribution close to a 'Fuller distribution' (Fuller and Thompson 1907). The mixture production rate for the FE experiment was approximately $2000 \mathrm{~kg}$ per $\mathrm{h}$.

\section{Backfilling machine}

\subsection{Backfilling concept}

A 'backfilling machine' (BFM) is needed to backfill a horizontal disposal tunnel with GBM as tightly and homogeneously as possible. Density is considered the key property for ensuring adequate long-term performance of the bentonite-based backfill material in a repository since it directly influences the safety-relevant attributes such as swelling pressure, gas- and water permeability, porosity and suppression of microbial activity. Suppression of microbial activity sets perhaps the most stringent density requirement. Stroes-Gascoyne (2011) reported that microbial activity is clearly suppressed in highly compacted bentonite. Leupin and Johnson (2013) concluded that a saturated density of $1.90 \mathrm{~g} / \mathrm{cm}^{3}$ (corresponding to a DD of $1.45 \mathrm{~g} / \mathrm{cm}^{3}$ ) for MX-80 bentonite is a desirable target as it may decrease the likelihood of microbially induced corrosion.

Based on the experience from the EB experiment (Kennedy and Plötze 2004) and the ESDRED project (Plötze and Weber 2007), the decision was made to design and fabricate a BFM with five screw conveyors for the FE experiment. The aim of using five screw conveyors was to improve the backfilling quality in terms of homogeneity, since segregation effects had been observed during previous projects. A staggered alignment of the screw conveyors was chosen with respect to the expected slope angle of the backfilled material. Moreover, an increased compaction was expected as each screw conveyor was designed to remain within the material bulk, building up a conveyance pressure.

\subsection{Backfilling pre-tests}

Before the BFM was constructed, Two pre-tests were carried out at a test facility close to Flums in Switzerland (Köhler et al. 2015). The first pre-test (performed in September 2012) focused on the coupled effects of (i) the material conveyance, (ii) the resulting backfilling pressure, (iii) the potential to push the material upwards and (iv) the corresponding actuation parameters of the screw conveyors. It was found that the ESDRED screw conveyors had the power to push GBM up to $70 \mathrm{~cm}$ upwards, if the resulting push back forces were kept under control by strong brakes. 
The second pre-test (performed in March 2013) aimed at (i) a better understanding of the bulk material behaviour as influenced by additional measures (such as slope coverage, insertion of vibration needles, etc.) and (ii) collecting data on the achievable bulk DD with regard to the grain size distribution of the GBM. It was found that, without additional measures (such as a slope coverage), small material avalanches occur at the front of the slope, resulting in 'firtree like' segregation effects in the backfilled material (Fig. 14).

\subsection{Machine construction}

In line with the Swiss disposal concept, the backfilling system for the FE experiment was designed to fit into small diameter disposal tunnels. With a view to operational robustness and precision, all machinery was developed railbound. An additional benefit of the rail-bound system in the FE experiment was precise manoeuvrability and therefore the reduced risk of collision with the experimental instrumentation.

The backfilling system consists of the BFM with a screw conveyance system and the feeding wagon (Fig. 15). The feeding wagon was designed as a vehicle carrying 4 bigbags (containing the GBM needed for backfilling) hanging on rollers to be pushed forward manually as soon as the bigbag in the front was emptied and removed. The feeding wagon for the FE experiment has no demonstration character with regard to the Swiss disposal concept; it is purely an economical solution for a non-industrial scale experiment.
The core component of the BFM is the conveyance unit. It consists of a horizontal discharging screw conveyor placed below the feeding hopper and a vertical and a horizontal feeding conveyor towards the distribution box. The latter is equipped with level transmitters to adjust the speed of the discharging screw and thus provides optimum conditions for the GBM to flow steadily through the distribution box into the five horizontal screw conveyors. These are aligned in a staggered manner with respect to the (approximately $35^{\circ}$ ) material slope in the backfilled tunnel. The tips of the screw conveyor tubes are cut obliquely in order to push the conveyed material upwards. During backfilling, all screw conveyors remain in the GBM slope in order to prevent dust formation and to build up a backfilling pressure. This pressure pushes the material upwards, also filling irregular cavities in the upper part of the tunnel profile.

The BFM is held in place by hydraulic brakes (until a repulsive force of $32 \mathrm{kN}$ is reached) in order to maintain a high backfilling pressure. The machine parameters such as each actuator's power consumption, rotation speed and the hydraulic braking force can be regulated using sophisticated controls (Jenni and Köhler 2015).

\subsection{Mock-up backfilling tests}

Before acceptance of the prototype BFM, it had to be extensively tested (Köhler et al. 2015). For this purpose, a test site was set up at a workshop in Grono, Switzerland, where all relevant processes related to heater emplacement and backfilling could be tested (Fig. 16). Temporary rails
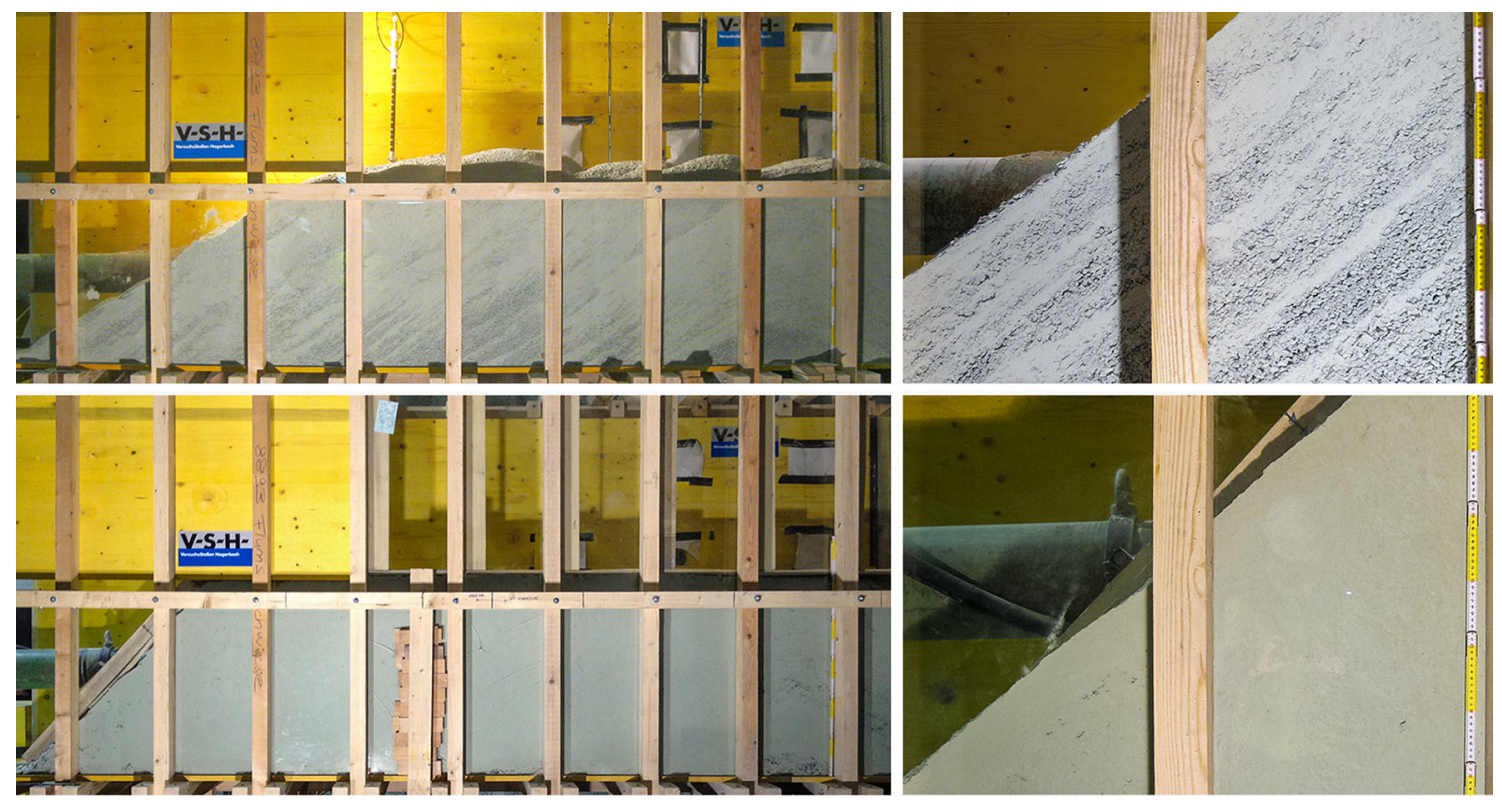

Fig. 14 'Fir-tree like' segregation effects due to small material avalanches at the slope as seen in the second pre-test (top pictures) can easily be avoided by covering the slope, e.g. with a flexible mat (bottom pictures) 


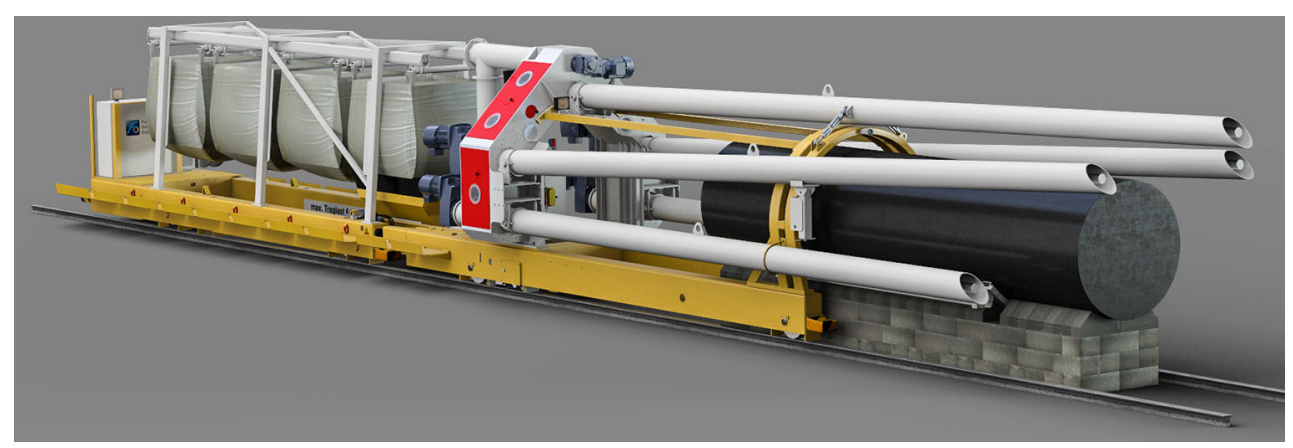

Fig. 15 Visualisation of the prototype 'backfilling machine' (BFM) with its five screw conveyors (driving over an approximately $1 \mathrm{~m}$ diameter canister on a bentonite block pedestal) developed for backfilling the horizontal FE tunnel. The total length of the BFM (including the feeding wagon with the four bigbags containing the GBM) is $17 \mathrm{~m}$

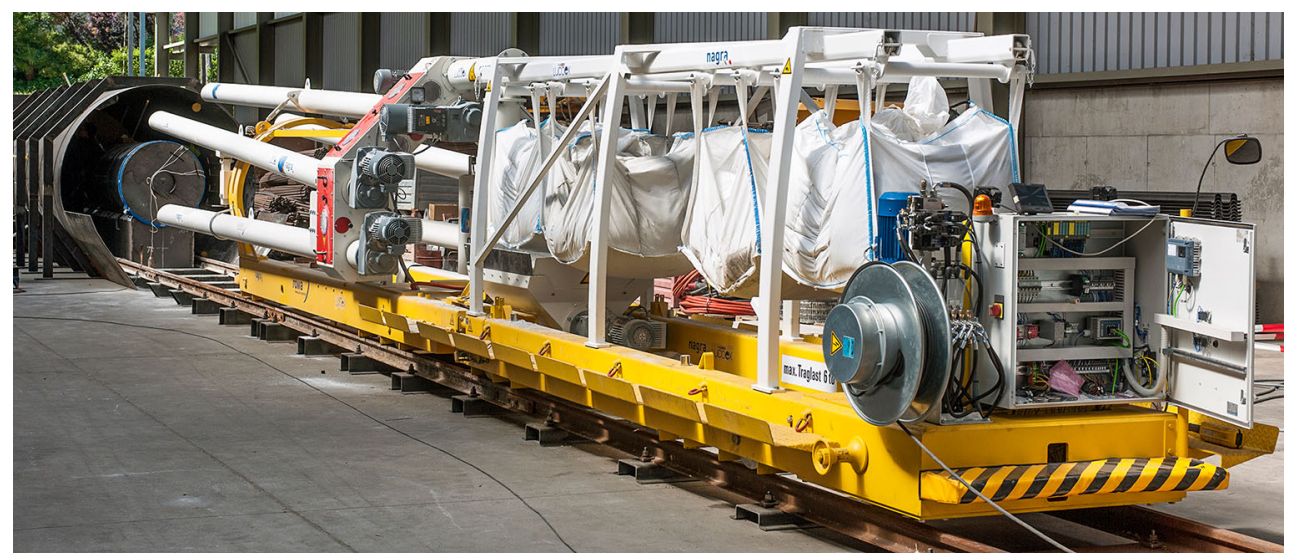

Fig. 16 Photo (by COMET) of the prototype BFM (with the control unit at the back and the feeding unit carrying four bigbags) during the mockup backfilling test at a workshop in Grono, Switzerland

and a full-scale 'test tunnel' (made of industrial steel sheets) with a diameter of $2.5 \mathrm{~m}$ and a length of $8 \mathrm{~m}$ were installed. The test set-up had the advantage that the backfilled material could be accessed not only through the slope, but also radially through the wall of the 'test tunnel'. Local density measurements were performed with dielectric sensors and radioactive logging tools as well as horizontal 'cone penetration testing' (CPT) equipment.

This 'test tunnel' was filled twice within the framework of the FE experiment. During the first mock-up backfilling test performed in May 2014, the focus was on technical functionality and procedural optimisation. During the second mock-up backfilling test performed in August 2014, the backfilling process was optimised in order to achieve higher bulk densities.

Regarding 'quality control' (QC) measures, the bulk density was calculated by mass-volume balance (=backfilled weight divided by backfilled volume). In the first mock-up backfilling test, the volume was estimated by combining the known geometry of the 'test tunnel' and the application of a 3D camera based on time-of-flight technology to capture the slope geometry. For the second mock-up backfilling test, the slope was laser scanned with a geodetic total station.

The average bulk DDs achieved with the mock-up backfilling tests are listed in Table 4 . The target DD of $1.45 \mathrm{~g} / \mathrm{cm}^{3}$ was clearly exceeded, especially around the canister where a bulk DD of approximately $1.53 \mathrm{~g} / \mathrm{cm}^{3}$ was reached. At the same time, the required functionality demonstration of the BFM, before using it at the Mont Terri rock laboratory, was performed successfully.

\section{Emplacement and backfilling}

The backfilling of the FE tunnel was performed in several steps (Köhler et al. 2015). The filling of the deep end of the FE tunnel was done in July 2014 with porous concrete for a potential future artificial saturation of the bentonite block wall.

\subsection{Bentonite block wall}

In the FE tunnel, a $2 \mathrm{~m}$ long bentonite block wall was constructed in the 'interjacent sealing section' (ISS) 
Table 4 Bulk dry densities calculated from mass-volume measurements in the two full-scale mock-up backfilling tests in Grono, Switzerland

\begin{tabular}{lllll}
\hline Mock-up backfilling test & No. 1 (overall) & No. 2 (behind canister) & No. 2 (around canister) & No. 2 (overall) \\
\hline Bulk dry density & $1.498 \mathrm{~g} / \mathrm{cm}^{3}$ & $1.490 \mathrm{~g} / \mathrm{cm}^{3}$ & $1.525 \mathrm{~g} / \mathrm{cm}^{3}$ & $1.502 \mathrm{~g} / \mathrm{cm}^{3}$ \\
Deviation & \pm 0.023 & \pm 0.013 & \pm 0.022 & \pm 0.009
\end{tabular}

between TM44.65 and TM46.65 to (i) investigate what DD can reasonably be expected with bentonite blocks assembled in such a tunnel section, (ii) verify the construction feasibility of a bentonite block wall considering the irregular tunnel surface and (iii) be able to potentially measure the sealing effectiveness of the wall at a later experimental stage.

The construction of the bentonite block wall (Fig. 17) took place in early September 2014, when the RH of the seasonally changing tunnel air in the Mont Terri rock laboratory was at around $80-85 \%$. The bentonite blocks survived the 2 weeks of emplacement without any degradation.

In total, about $14 \mathrm{~m}^{3}$ of bentonite blocks were emplaced manually within Nine working days. The average DD of each block was $1.78 \mathrm{~g} / \mathrm{cm}^{3}$; the average WC was $18 \%$. Finally, a global bulk DD of $1.69 \pm 0.05 \mathrm{~g} / \mathrm{cm}^{3}$ was achieved for the entire bentonite block wall.

\subsection{Bentonite block pedestal}

As preparation for each heater emplacement and backfilling, a bentonite block pedestal was assembled on a prepared concrete surface. Because of the numerous sensors and cables within this bentonite block pedestal, the work was done manually, not exhibiting any demonstration character with respect to the Swiss disposal concept. Each bentonite block pedestal was $4.4 \mathrm{~m}$ long, $0.8 \mathrm{~m}$ wide and $0.54 \mathrm{~m}$ high. In total, each pedestal consisted of 132

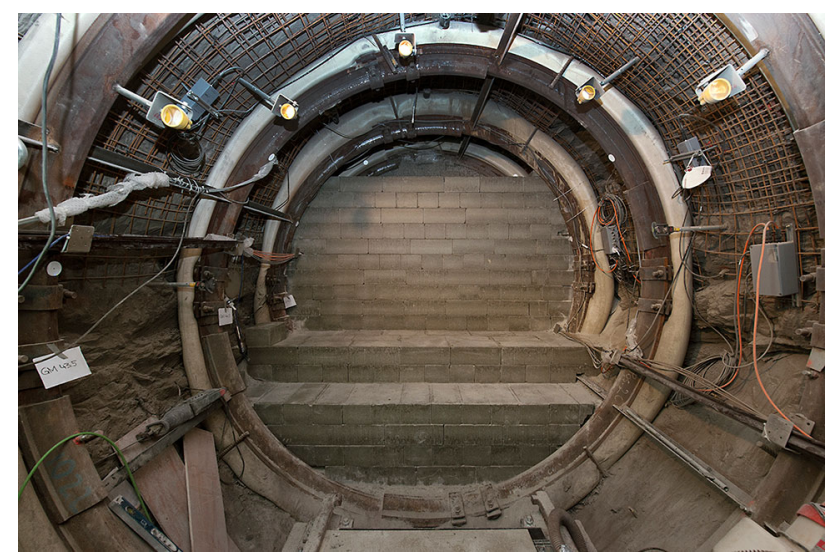

Fig. 17 Photo (by COMET) of the unfinished bentonite block wall in the 'interjacent sealing section' (ISS) at the deep end of the FE tunnel rectangular bentonite blocks (à $24.4 \mathrm{~kg}$ ) and 88 curved top layer bentonite blocks (à $11.65 \mathrm{~kg}$ ).

After the completion of each bentonite block pedestal, the appropriate heater was driven into the FE tunnel with an emplacement wagon specially designed for this purpose. After precisely manoeuvring the $5000 \mathrm{~kg}$ heater over the heavily instrumented pedestal, the heater was carefully lowered onto the pedestal with the help of hydraulic cylinders, avoiding any point loads on the bentonite blocks.

In this manner, heater $\mathrm{H} 1$ was emplaced in October 2014, heater H2 (Fig. 18) in November 2014 and heater H3 in January 2015. Due to the intensive instrumentation, cable routing and QC work, the construction of one bentonite block pedestal including the associated heater emplacement took between 8 and 13 working days.

\subsection{Backfilling}

First, the remaining $6.6 \mathrm{~m}$ of the ISS were backfilled with the help of the BFM. A total of around 70,000 $\mathrm{kg}$ of GBM were emplaced in the ISS within four working days. The large cavities, particularly in the top part of the tunnel, were filled without any problems.

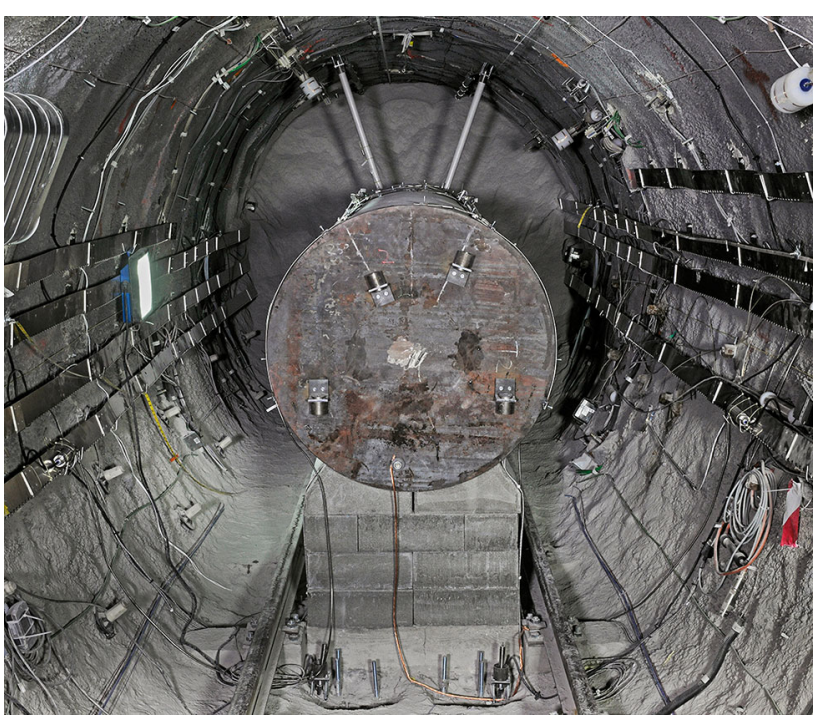

Fig. 18 Photo (by COMET) of a bentonite block pedestal supporting a heavily instrumented heater in the FE tunnel. The greyish mass in the background is a slope of GBM backfilled prior to the construction of the pedestal. The cable routing channels made from stainless steel can be seen on the tunnel wall 
After the construction of each bentonite block pedestal and the subsequent emplacement of the associated heater, each section was then backfilled individually. The BFM (Fig. 19) with its $8.5 \mathrm{~m}$ long top screw conveyor was designed to be able to drive over the bentonite block pedestal with the emplaced heater so that the screw conveyor tips could still be inserted into the (last) GBM slope (covering the preceding bentonite block pedestal and heater).

Each feeding wagon carried 4 bigbags of GBM, which corresponded to approximately $0.5-0.75 \mathrm{~m}$ of backfilled length in the FE tunnel. To complete the whole sequence for each heater, around 60 bigbags (each with a weight of $1000 \mathrm{~kg}$ ) had to be backfilled, resulting in the feeding wagon being reloaded 15 times. The reloading of bigbags was done at a distance of $75 \mathrm{~m}$ from the FE tunnel at the intersection of the MB tunnel with GA08, while the backfilling unit remained in the FE tunnel with the screw conveyor tips inserted in the GBM slope. This sequence was repeated for each of the three heaters. Backfilling one $4.5 \mathrm{~m}$ long heater including the $3 \mathrm{~m}$ long gap between two heaters took 2-3 working days. Together with the relevant section of the ISS and the volume towards the plug, $29.6 \mathrm{~m}$ of the FE tunnel were filled with approximately $255,000 \mathrm{~kg}$ of GBM.

Each of the 11 times the BFM was driven out of the FE tunnel, for instrumentation and QC purposes the available GBM slopes were scanned with a 3D laser scanner in order to determine the backfilled volumes. Together with the weighing of each bigbag used for backfilling, the backfilled bulk DD was calculated for each of these 12 sections (Fig. 20). Considering the disturbance by e.g. sensors and cables, the global DD of approximately $1.49 \mathrm{~g} / \mathrm{cm}^{3}$

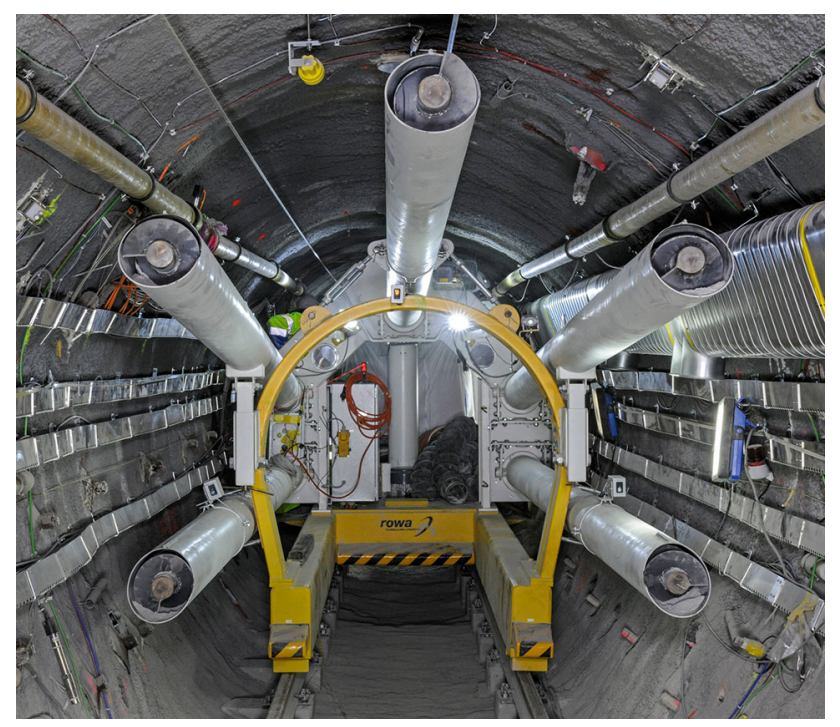

Fig. 19 Photo (by COMET) of the prototype BFM in the FE tunnel at the Mont Terri rock laboratory achieved in the FE tunnel without any break-downs or accidents can be considered as a very satisfactory result.

\section{Plug}

The backfilling of the FE tunnel was completed by stepwise construction of a vertical retaining wall in February 2015. This retaining wall consisted of $20 \mathrm{~cm}$ thick (according to the tunnel geometry pre-fabricated) concrete segments stacked in five rows. The interface of this retaining wall with the backfilled GBM was located at TM15. Finally, the retaining wall was sealed with two layers of resin in order to reduce vapour and gas transport. In total, approximately 750 sensors and heater cables had to be routed through this retaining wall. They were guided through the plug in two separate tubes which were filled with resin to reduce vapour and gas transport.

After the completion of this preparatory work, the plug was constructed. The FE plug was designed to withhold the potential swelling pressure of a fully saturated bentonite backfill (approximately $3 \mathrm{MPa}$ for an average bulk DD of around $1.45 \mathrm{~g} / \mathrm{cm}^{3}$ ), although full saturation is not expected to occur within the experiment monitoring period (approximately $10-15$ years) because of the low permeability of the surrounding rock. The conservative design of this 'friction controlled' plug was achieved with the installation of 50 steel dowels inserted perpendicularly into the rockshotcrete lining-plug interface. On the 17th of March $2015,31 \mathrm{~m}^{3}$ of self-compacting concrete were pumped into the space between the retaining wall at TM14.8 and the formwork placed at TM9.8. In order to limit the curing temperature to a maximum of $50{ }^{\circ} \mathrm{C}$, a major part of the cement (around 50\%) was replaced by fly ash. 40 days after casting, the shrinkage gap at the shotcrete lining-plug interface, estimated to be less than $1 \mathrm{~mm}$ and resulting from settlement of the fresh concrete and from drying, was injected with resin with a pressure of $0.5 \mathrm{MPa}$.

With the plug construction, and particularly with the removal of the formwork, the on-site work in connection with the implementation of the FE experiment at the Mont Terri rock laboratory was completed successfully.

\section{Heating}

For the FE experiment, three customised heaters each with a length of $4.6 \mathrm{~m}$ and a diameter of $1.05 \mathrm{~m}$ were manufactured and then emplaced in the FE tunnel. The heaters were designed as hollow carbon steel cylinders in order to allow the installation of electrical resistance heating cables on the inside. This set-up resulted in a heater weight of $5000 \mathrm{~kg}$ each. 


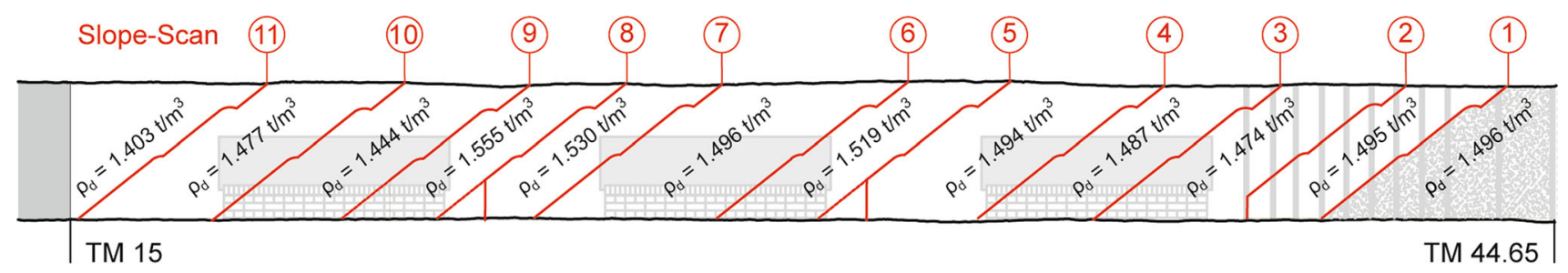

Fig. 20 Longitudinal section of the backfilled FE tunnel indicating the position of the 3D slope scans and the resulting bulk dry densities calculated for each of the sections. Around the five screw conveyor

After the heater emplacement and the subsequent backfilling, the heating phase was started in December 2014 with the 'deepest' heater H1 first. Finally, in February 2015, the middle heater $\mathrm{H} 2$ and the 'shallow' heater $\mathrm{H} 3$ close to the plug were turned on (Fig. 21). The heaters are run power-controlled, meaning that the temperature is not fixed and is therefore an experimental outcome. The resulting temperature distribution is influenced mainly by the thermal properties of the (at the beginning relatively dry and therefore poorly heat-conducting) bentonite backfill, but also by the thermal properties of the rock and the boundary conditions at the Mont Terri rock laboratory.

According to current plans, the initial power level of 1350 Watt per heater will be kept constant for at least the first 3 years after the start of heating. Afterwards, it is currently planned to decrease the power according to a decay function typical for spent fuel. The heating and monitoring phase of the FE experiment at Mont Terri is envisaged to last at least $10-15$ years. First temperature measurements from the surface of $\mathrm{H} 1$ and the comparison to the numerical simulations and predictions are shown in Fig. 22.

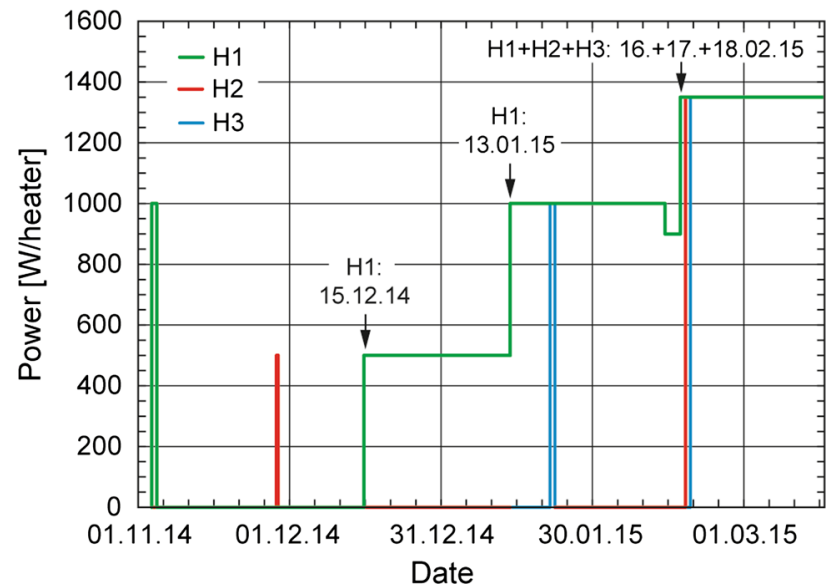

Fig. 21 Time series plot showing how the (power-controlled) heating of the FE experiment at Mont Terri rock laboratory was started. The 'deepest' heater $\mathrm{H} 1$ was backfilled and turned on first. The first power step at 500 Watt was started on 15th of December 2015. After 1 month the power was increased to 1000 Watt. Finally, on 16th, 17th and 18th of February 2015, all three heaters were turned on successively to a power level of 1350 Watt for each heater outlets, the bulk dry density locally reached approximately $1.7 \mathrm{~g} / \mathrm{cm}^{3}$; a value comparable to the bulk dry density of a bentonite block pedestal

\section{Concluding remarks}

Within the framework of the FE experiment, the construction of a disposal tunnel in Opalinus Clay using standard industrial equipment and horizontal canister emplacement and backfilling were successfully tested. During the production of the GBM, the material treatment, pelletisation, grinding and mixing were studied in a systematic way and optimised in order to obtain properties that fulfil all requirements. The resistance of the bentonite blocks to varying tunnel climate conditions was improved by optimisation of the production parameters.

Experience from previous experiments led to the design of a prototype BFM with five screw conveyors, allowing the horizontal backfilling of disposal tunnels with GBM as densely and homogeneously as possible. After construction, this machine underwent intensive testing. The minimum bulk DD of $1.45 \mathrm{~g} / \mathrm{cm}^{3}$, as targeted for the bentonite backfill according to the Swiss repository concept, was exceeded in the mock-up backfilling tests and in the FE tunnel without any break-downs or accidents. The optimisation, industrialisation and automation of these

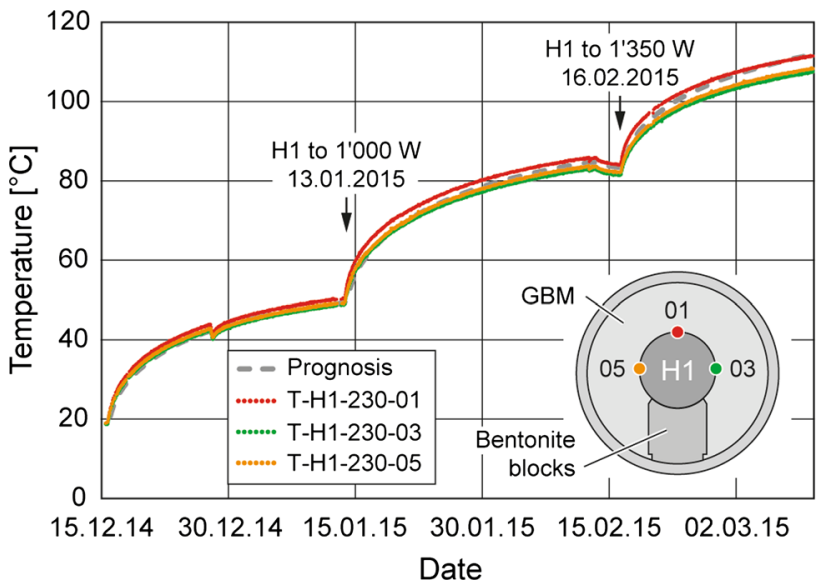

Fig. 22 Time series plot showing how the surface temperature of the 'deepest' heater $\mathrm{H} 1$ reacted to the selected turn-on sequence. The calculated temperature prediction for an initially (with a water content of approximately $5 \%$ ) relatively dry GBM with a thermal conductivity of $0.3 \mathrm{~W} / \mathrm{mK}$ is represented as a dashed grey line in the background 
processes can be completed in the decades remaining until the start of repository operation.

The main aim of the FE experiment at the Mont Terri rock laboratory is the investigation of repository-induced effects and validation of existing coupled THM models. Three electrical heaters with dimensions similar to those of future canisters were emplaced in the FE tunnel before backfilling. All heaters were turned on between December 2014 and February 2015 and are planned to constantly emit 1350 Watt each, at least for the first 3 years. Afterwards it is planned to decrease the power according to a decay function typical for spent fuel.

For monitoring the effects of this full-scale heating on the backfill and the host rock, several hundred sensors were installed in and around the FE tunnel. These sensors measure various parameters such as temperature, pressure, deformation, humidity/water content, gas composition, etc. At the end of the continuous heating period, temperatures of approximately $130-150{ }^{\circ} \mathrm{C}$ at the surface of the middle heater and approximately $60-80{ }^{\circ} \mathrm{C}$ at the rock surface are expected.

The FE experiment can be considered a very important step with a potentially significant outcome for the Swiss disposal concept. It could have a direct influence on the design of future disposal tunnels and also on the loading of the future repository canisters.

Acknowledgements This work is dedicated to the late Peter Blümling, who was one of the main initiators of the FE experiment. The FE experiment was implemented at the Mont Terri rock laboratory, which is operated by swisstopo. The initiator and lead organisation of the FE experiment is Nagra (Switzerland). We thank ANDRA (France), BGR (Germany), DOE/LBNL (USA), GRS (Germany) and NWMO (Canada) for participating in the FE experiment. We also acknowledge our colleagues from swisstopo for their continuous help and efforts during the on-site work. The engineering and demonstration components of the FE experiment were also part of Nagra's participation in the EU project 'Large Underground COncept EXperiments' (LUCOEX); parts of the research leading to these results have therefore received funding from the European Union's European Atomic Energy Community's (Euratom) Seventh Framework Programme FP7/2007-2013 under Grant Agreement No. 269905. We are grateful to Bruno Kunz for enhancing the figure quality, Linda McKinley for improving the English of the manuscript and Petra Blaser for the consistency check. Last but not least we thank the reviewers Klaus Wieczorek (Gesellschaft für Anlagen- und Reaktorsicherheit $\mathrm{GmbH}$, Braunschweig, Germany) and Jan Verstricht (Belgian Nuclear Research Centre, Mol, Belgium) for their time and constructive feedback helping to further improve the quality of this publication.

Open Access This article is distributed under the terms of the Creative Commons Attribution 4.0 International License (http://crea tivecommons.org/licenses/by/4.0/), which permits unrestricted use, distribution, and reproduction in any medium, provided you give appropriate credit to the original author(s) and the source, provide a link to the Creative Commons license, and indicate if changes were made.

\section{References}

Alonso, M. C., García Calvo, J. L., Walker, C., Naito, M., Pettersson, S., Puigdomenech, I., et al. (2012). Development of an accurate $\mathrm{pH}$ measurement methodology for the pore fluids of low $\mathrm{pH}$ cementitious materials. SKB report, $R-12-02$. Swedish Nuclear Fuel and Waste Management, Stockholm, Sweden. www.skb.se.

Bernier, F., Li, X.-L., \& Bastiaens, W. (2007). Twenty-five years' geotechnical observation and testing in the Tertiary Boom Clay formation. Géotechnique, 57(2), 229-237.

Blümling, P., \& Adams, J. (2008). Grimsel test site investigation phase IV: Borehole sealing. Nagra Technical Report, NTB 07-01. Nagra, Wettingen, Switzerland. www.nagra.ch.

Bosgiraud, J. M., Nachmilner, L., Hooper, A., Pettersson, S., Fries, T., Verstricht, J., et al. (2015). Expert group report. EU project LUCOEX, deliverable D1.14. www.lucoex.eu.

Bossart, P., Bernier, F., Birkholzer, J., Bruggeman, C., Connolly, P., Dewonck, S., Fukaya, M., Herfort, M., Jensen, M., Matray, J-M., Mayor, J. C., Moeri, A., Oyama, T., Schuster, K., Shigeta, N., Vietor, T., \& Wieczorek, K. (2017). Mont Terri rock laboratory, 20 years of research: Introduction, site characteristics and overview of experiments. Swiss Journal of Geosciences, 110. doi:10.1007/s00015-016-0236-1 (this issue).

Daneluzzi, R., Burrus, F., Küttel, T., Müller, H. R., \& Köhler, S. (2014). Report on the construction of the emplacement tunnel. Nagra working report, NAB 14-54, Nagra, Wettingen, Switzerland and EU Project LUCOEX, Deliverable D2.2. www.lucoex. eu.

Fuller, W. B., \& Thompson, S. E. (1907). The laws of proportioning concrete. Journal of Transportation Engineering-ASCE, 59, 67143.

Garitte, B., Weber, H. P., \& Müller, H. R. (2015). Requirements, manufacturing and QC of the buffer components. Nagra Working Report, NAB 15-24, Nagra, Wettingen, Switzerland and EU Project LUCOEX, Deliverable D2.3. www.lucoex.eu.

Gaus, I., Wieczorek, K., Schuster, K., Garitte, B., Senger, R., Vasconcelos, R., et al. (2014). EBS behaviour immediately after repository closure in a clay host rock: HE-E experiment (Mont Terri URL). Geological Society, London, Special Publications, 400(1), 71-91.

Gens, A., Vaunat, J., Garitte, B., \& Wileveau, Y. (2007). In-situ behaviour of a stiff layered clay subject to thermal loading. Observations and interpretation. Géotechnique, 57(2), 207-228.

Gens, A., Wieczorek, K., Gaus, I., Garitte, B., Mayor, J.C., Schuster, K., Armand, G., García-Siñeriz, J-L., Trick, T. (2017). Performance of the Opalinus Clay under thermal loading: experimental results from Mont Terri rock laboratory (Switzerland). Swiss Journal of Geosciences, 110. doi:10.1007/s00015-016-0258-8 (this issue).

Gugala, J. (2015). Final report LUCOEX-WP3. ALC full scale emplacement experiment. EU project LUCOEX, deliverable D3.4. www.lucoex.eu.

Hoffmann, C., Alonso, E. E., \& Romero, E. (2007). Hydromechanical behaviour of bentonite pellet mixtures. Physics and Chemistry of the Earth, 32, 832-849.

Hostettler, B., Reisdorf, A.G., Jaeggi, D., Deplazes, G., Bläsi, H.-R., Morard, A., Feist-Burkhardt, S., Waltschew, A., Dietze, V., Menkveld-Gfeller, U. (2017). Litho- and biostratigraphy of the Opalinus Clay and bounding formations in the Mont Terri rock laboratory (Switzerland). Swiss Journal of Geosciences, 110. doi:10.1007/s00015-016-0250-3 (this issue).

Jenni, H., \& Köhler, S. (2015). Full-scale emplacement (FE) experiment: Report on the construction, testing and commissioning of the emplacement equipment. Nagra working report, 
$N A B$ 15-25, Nagra, Wettingen, Switzerland and EU Project LUCOEX, Deliverable D2.4. www.lucoex.eu.

Jenni, A., Mäder, U., Lerouge, C., Gaboreau, S., \& Schwyn, B. (2013). In situ interaction between different concretes and Opalinus Clay. Physics and Chemistry of the Earth, Parts $A / B / C$, $70,71-83$.

Johannesson, L.-E., Gunnarsson, D., Sandén, T., Börgesson, L., \& Karlzén, R. (2004). Äspö Hard Rock Laboratory. Prototype repository. Installation of buffer, canisters, backfill, plug and instruments in Section II. SKB report, IPR-04-13. Swedish Nuclear Fuel and Waste Management, Stockholm, Sweden. www.skb.se.

Karnland, O. (2010). Chemical and mineralogical characterization of the bentonite buffer for the acceptance control procedure in a KBS-3 repository. SKB Report, TR 10-60. Swedish Nuclear Fuel and Waste Management, Stockholm, Sweden. www.skb.se.

Kennedy, K., \& Plötze, M. (2004). Engineered barrier emplacement (EB) experiment in Opalinus Clay: Granular material backfill emplacement method evaluation. EU project deliverable D4.

Köhler, S., Garitte, B., Weber, H. P., \& Müller, H. R. (2015). FE/ LUCOEX: Emplacement report. Nagra working report, NAB 1527, Nagra, Wettingen, Switzerland and EU Project LUCOEX, Deliverable D2.5. www.lucoex.eu.

Lanyon, G. W., \& Gaus, I. (Eds.) (2013). Main outcomes and review of the FEBEX in situ test (GTS) and mock-up after 15 years of operation. Nagra working report, NAB 13-96, Nagra, Wettingen, Switzerland. www.nagra.ch.

Leupin, O. X., \& Johnson, L. H. (2013). Buffer requirements for a SF/ HLW repository in Opalinus Clay. Nagra working report, $N A B$ 13-46, Nagra, Wettingen, Switzerland. www.nagra.ch.

Lisjak, A., Garitte, B., Grasselli, G., Müller, H. R., \& Vietor, T. (2015). The excavation of a circular tunnel in a bedded argillaceous rock (Opalinus Clay): Short-term rock mass response and FDEM numerical analysis. Tunnelling and Underground Space Technology, 45, 227-248.

Lothenbach, B., Rentsch, D., \& Wieland, E. (2014). Hydration of a silica fume blended low-alkali shotcrete cement. Physics and Chemistry of the Earth, $A / B / C, 70,3-16$.

Marschall, P., Giger, S., De La Vassie're, R., Shao, H., Leung, H., Nussbaum, C., et al. (2017). Hydro-mechanical evolution of the EDZ as transport path for radionuclides and gas: Insights from the Mont Terri rock laboratory (Switzerland). Swiss Journal of Geosciences, 110. doi:10.1007/s00015-016-0246-z (this issue).

Müller, H. R., Garitte, B., Köhler, S., Vogt, T., Sakaki, T., Weber, H. P., et al. (2015). FE/LUCOEX: Final report. Nagra working report, $N A B$ 15-28, Nagra, Wettingen, Switzerland and $E U$ Project LUCOEX, Deliverable D2.6. www.lucoex.eu.

Nagra. (2002). Projekt Opalinuston: Konzept für die Anlage und den Betrieb eines geologischen Tiefenlagers: Entsorgungsnachweis für abgebrannte Brennelemente, verglaste hochaktive sowie langlebige mittelaktive Abfälle. Nagra technical report, NTB 02-02. Nagra, Wettingen, Switzerland. www.nagra.ch.

Nagra. (2010). Beurteilung der geologischen Unterlagen für die provisorischen Sicherheitsanalysen in SGT Etappe 2. Klärung der Notwendigkeit ergänzender geologischer Untersuchungen. Nagra technical report, NTB 10-01. Nagra, Wettingen, Switzerland. www.nagra.ch.
Nagra. (2014). SGT Etappe 2: Vorschlag weiter zu untersuchender geologischer Standortgebiete mit zugehörigen Standortarealen für die Oberflächenanlage. Geologische Grundlagen. Nagra technical report, NTB 14-02. Nagra, Wettingen, Switzerland. www.nagra.ch.

Nussbaum, C., Kloppenburg, A., Cae"r, T., \& Bossart, P. (2017). Tectonic evolution around the Mont Terri rock laboratory, northwestern Swiss Jura: constraints from kinematic forward modelling. Swiss Journal of Geosciences, 110. doi:10.1007/ s00015-016-0248-x (this issue).

Leupin, O. X. Birgersson, M., Karnland, O., Korkeakoski, P., Mäder, U. K., Sellin, P., et al. (Eds.) (2014). Montmorillonite stability under nearfield conditions. Nagra technical report, NTB 14-12. Nagra, Wettingen, Switzerland. www.nagra.ch.

Pietsch, W. (2004). Agglomeration in industry: Occurrence and applications (Vol. 1). New York: Wiley.

Plötze, M., \& Weber, H. P. (2007). ESDRED Emplacement tests with granular bentonite MX-80. Laboratory results from ETH Zürich. Nagra working report, NAB 07-24, Nagra, Wettingen, Switzerland. www.nagra.ch.

Sakaki, T., Vogt, T., Müller, H. R., Wörsching, H., \& Vrzba, M. (2014). モンテリFE 試験におけるオパリナス粘土岩内含水量モニタ リング用TDR プローブの開発 [Development of TDR probes for monitoring water content in Opalinus Clay in the FE experiment at Mont Terri Rock Laboratory.] Proceedings of the 69th JSCE annual meeting, September 2014, Osaka, Japan.

Shao, H., Paul, B., Wang, X. R., Hesser, J., Becker, J., Garitte, B., \& Müller, H. R. (2015). Near-field permeability distribution of FE tunnel in the Mont Terri Rock Laboratory-Influence of shotcrete lining on EDZ development. Proceedings of the 6th international conference on clays in natural and engineered barriers for radioactive waste confinement, March 2015, Brussels, Belgium.

Stroes-Gascoyne, S. (2011). Microbiological characteristics of compacted bentonite at a dry density of $1450 \mathrm{~kg} / \mathrm{m}^{3}$-A literature review. Nagra working report, NAB 11-05, Nagra, Wettingen, Switzerland. www.nagra.ch.

Villar, M. V., Martín, P. L., Gómez-Espina, R., Romero, F. J., \& Barcala, J. M. (2012). Long-term THM tests reports: THM cells for the HE-E test: Setup and first results. PEBS report D2.2.7.1, CIEMAT technical report CIEMAT/DMA/2G210/02/2012. Madrid, Spain.

Vogt, T., Müller, H. R., Sakaki, T., \& Vietor, T. (2013). Monitoring THM effects in a full scale EBS/host rock system-First experiences of the FE-experiment in the Mont Terri URL during construction and ventilation phase. MoDeRn international conference and workshop, March 2013, Luxembourg. Deliverable D5.4.1, 326-334.

Weber, H. P., Köhler, S., Teodori, S., Müller, H. R., \& Vietor, T. (2012). Work plan, work package 2: Full scale emplacement experiment (FE) at Mont Terri. Nagra working report, NAB 1210. Nagra, Wettingen, Switzerland and EU Project LUCOEX, Deliverable D2.1. www.lucoex.eu.

Wetzig, V., Fries, T., \& Iglesias, E. (2011). Low-pH shotcrete: Application as rock support for radioactive waste disposal. Proceedings of the world tunnel congress. Helsinki, Finland. 